\title{
O Violão Oitocentista nos álbuns da Família Perdigão
}

\author{
Guilherme Augusto de Ávila, Daniel L. Cerqueira, Joaquim Santos Neto \\ Universidade Federal do Maranhão; Universidade Federal do Piauí | Brasil
}

\begin{abstract}
Resumo: No presente trabalho, dois álbuns de música da família Perdigão são estudados a partir da proveniência documental de Laura Agnes Millar. O estudo da proveniência focou os aspectos de custódias, marcos temporais da sua produção, e sua relação com o repertório nos locais onde seus proprietários viveram. Paralelamente, foi feito um estudo organológico do violão no Maranhão oitocentista, uma vez que os álbuns apresentam a questão da fixação de nomenclatura relativa ao instrumento. Como resultado, foi verificado que os álbuns foram produzidos ao longo do Império Brasileiro, mantidos por quatro gerações, e que o seu repertório expressa estreita relação com os traslados dos seus proprietários.
\end{abstract}

Palavras-chave: Família Perdigão, Violão, Século XIX, Álbuns de Música, Maranhão

\begin{abstract}
In the present work, two Perdigão family music albums are studied from Laura Agnes Millar's documentary provenance. The provenance study focused on custody aspects; timelines of their production, and their relationship with the repertoire in the places where their owners lived. At the same time, an organological study of the guitar was made in 19th century Maranhão, since the albums present the question of fixing the nomenclature related to the instrument. As a result, it was found that the albums were produced throughout the Brazilian Empire; maintained for four generations, and that its repertoire is closely related to the transfers of its owners.
\end{abstract}

Keywords: Perdigão Family. Guitar, 19th Century, music albums, Maranhão. 


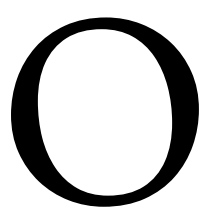

s álbuns de música da família Perdigão (Figura 1) representam os documentos com o maior número de registros de obras para violão do Maranhão oitocentista ${ }^{1}$. Das 136 peças presentes nos dois álbuns, 70 são para violão solo; 2 para canto e violão e uma para guitarra inglesa, enquanto que as demais 63 músicas se dividem entre 2 peças para piano solo; 20 para canto e piano; 23 para violino; 13 melodias sem indicação de instrumento, e 5 peças para pequenos grupos. Eles se encontram no Museu Histórico Artístico do Maranbão (MHAM), sob os registros 291/74 e 292/74 do Livro de Tombo (MARANHÃO, 1974).

Além da suposição mais direta de que esses álbuns oferecem um estrato do repertório que circulava na São Luís de sua época, uma série de questôes apontaram para a necessidade de um estudo musicológico transdisciplinar como: quais membros da família Perdigão produziram/possuíram os álbuns? Quais etapas da trajetória de cada um desses indivíduos podem ser relacionadas às informações contidas nas fontes? Qual a relação do seu repertório com os locais por onde seus proprietários circularam? Qual o motivo da alternância de denominações para o instrumento violão nos álbuns? Tendo em vista tais perguntas, apresentam-se a seguir as ferramentas/estratégias abordadas.

FIGURA 1 - Capas dos dois álbuns da família Perdigão (reg. 291 e 292/74).

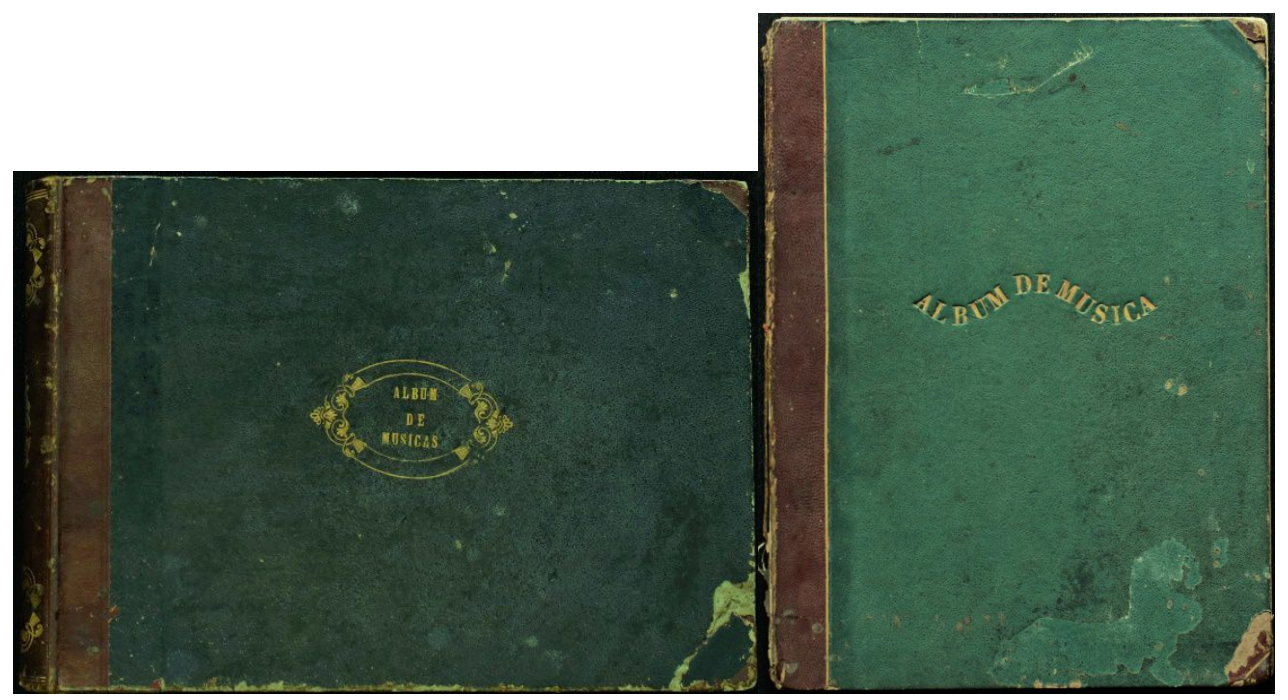

Fonte: Museu Histórico Artístico do Estado do Maranhão, 2018.

\footnotetext{
${ }^{1}$ Além destes álbuns, há uma folha contendo música para canto e violão, do ano de 1891 . Ela se encontra no Arquivo Público do Estado do Maranhão (APEM), e integra o Acervo João Mohana (MAP.02; ENV.1050). Disponível em: apem.cultura.ma.gov.br/acervo.
} 


\section{Marco Teórico}

A presente proposta tem Laura Agnes Millar (2015) como marco teórico. Nesta proposta, a história do documento; história do(s) seu(s) produtor(es) e a respectiva história arquivística são utilizadas na compreensão da proveniência documental. Laura aponta a falibilidade na noção de completude dos fundos arquivísticos, segundo a qual, a proveniência deve servir como referência na compreensão do documento. Millar utiliza aproximaçóes com a Arqueologia e Museologia para demonstrar o quanto os fundos são incompletos e o quanto a proveniência deve ser a chave para a compreensão da história do documento:

Mas o arqueólogo não declara de forma unilateral que um fragmento de cerâmica é um penico. E um curador não tem a pretensão de equiparar uma pintura de Picasso à soma total de suas obras. Em vez de fazer de conta que temos a posse dos fundos, nós arquivistas devemos explicar o que realmente possuímos; explicar a história temporal e espacial do fundo e deixar os usuários criarem as conexôes e estabelecer suas próprias definiçóes de "totalidade" (MILLAR, 2015, p. 155).

Ao discutir a validade do estudo da proveniência (procedência) em arquivos musicais familiares ou pessoais, Cabezas Bolaños afirma que esses documentos são produzidos por um organismo, e que isso atesta suas atividades através do tempo. Portanto, eles são providos de significados igualmente analisáveis arquivisticamente.

Ao falar em proveniência documental, devemos analisar a existência de um organismo produtor que plasme em seu fundo documental suas funções substantivas, de maneira que um dos elementos fundamentais que marcam a proveniência são os conceitos de produção, pertencimento, origem junto à relação destes conceitos com um determinado período histórico e seu vínculo com o gerador ${ }^{2}$ (CABEZAS BOLAÑOS, 2005, p.86. Tradução nossa).

Dessa forma, o estudo da proveniência será utilizado como auxílio às questóes surgidas durante o processo de análise in loco. Essas questôes têm estreita relação com a história dos seus produtores; história dos documentos e de seu arquivamento.

\footnotetext{
${ }^{2} \mathrm{Al}$ hablar de procedencia documental debemos analizar la existencia de un organismo productor que plasme en su fondo documental sus funciones sustantivas, de manera que uno de los elementos fundamentales que marcan la procedencia son los conceptos de producción, pertenencia, origen junto a la relación de estos conceptos con un determinado período histórico y su vínculo con el generador.
} 


\subsection{História dos proprietários}

O estudo da biografia da família Perdigão se revelou uma ferramenta de extrema utilidade no enquadramento histórico dos álbuns, bem como na compreensão de uma série de fatores temporais de custódias e percurso musical de seus proprietários. Assim, foi possível compreender que eles foram produzidos entre as décadas de 1820 e 1890, permanecendo em uso por cerca de 145 anos e passados de pai para filho por quatro gerações da família Perdigão.

\subsection{História da produção}

Através da história da sua produção foi possível observar que ela abarca a totalidade do período Imperial (1822-1889), mas seu uso, sem acréscimo de conteúdo, adentrou a República. A análise in loco detectou marcos temporais da sua produção, bem como mudanças de caligrafia e a sequência do seu repertório corrobora as informações acerca do seu histórico de produção. Por conta deste período de produção, eles foram contextualizados na São Luís Imperial, apontando para seu significado na vida da família Perdigão.

Uma análise da linha temporal dos álbuns, no que concerne ao repertório violonístico, revela a predominância de excertos de óperas encenadas contemporaneamente em São Luís, havendo também valsas, polcas, mazurcas e temas com variações tanto de autores europeus quanto maranhenses de sua época. Também foi possível perceber o quanto o violão está fortemente ligado ao seu segundo utilizador, Domingos Thomaz Vellez Perdigão (1842-1899), que, apesar de ser adepto deste instrumento e ter exercido a profissão de professor de música, jamais figurou como professor de violão especificamente, nem mesmo como intérprete em apresentações públicas.

\subsection{História arquivística}

O estudo da história de produção e dos proprietários dos álbuns contribuiu na revelação da sua história arquivística. Eles possibilitaram a constatação dos seus diferentes momentos de custódia, assim como os fatores que determinaram a sua atual destinação, no Museu Histórico Artístico do 
Maranbão - MHAM, sob registros 291/74 e 292/74 do Livro de Tombo da instituição (MARANHÃO, 1974).

\section{Justificativa}

$\mathrm{Na}$ atualidade, ainda é incipiente o status da pesquisa biográfica de uma família tão importante para a compreensão da música no Maranhão oitocentista como a dos Perdigão. Entre eles, o supracitado Domingos Thomaz Vellez Perdigão é o personagem que mais se destaca, tendo deixado pelo menos três documentos musicais que são representativos da vida musical maranhense no oitocentos. São eles: os Princípios Elementares de Música em 10 Liçôes (PERDIGÃO, 1869), obra didático-musical maranhense mais antiga que sobreviveu ao tempo; e a sua participação na produção dos dois álbuns de música, em que o violão figura como instrumento mais recorrente. No presente trabalho, concentramo-nos nestes dois álbuns, uma vez que o livro supracitado já foi estudado por outros pesquisadores (DANTAS FILHO, 2006; SALOMÃO, 2017).

Outro fator que nos imbui em tal estudo é que o violão maranhense do oitocentos ainda não foi satisfatoriamente estudado. O Maranhão já possui trabalhos acerca de uma parcela do repertório litúrgico (CARVALHO SOBRINHO, 2011; DANTAS FILHO, 2006; SANTOS NETO, 2009; CARVALHO SOBRINHO, 1989); das operetas cômicas (CARVALHO SOBRINHO, 2010); do repertório de concerto (PÁSCOA, 2009; CERQUEIRA, 2019); do repertório de choro (ALVES, 2012; COSTA NETO, 2015); do repertório das bandas militares (SANTOS, 2019); do ensino musical (SALOMÃO, 2017; FERREIRA, 2017); do piano (SILVA, 2015; CERQUEIRA, 2019); do contexto histórico-cultural (GOUVEIA NETO, 2010; SANTOS, 2012); e das características do Acervo João Mohana (MOHANA, 1995; CARVALHO SOBRINHO, 2003a/2003b; DUARTE, 2016; CERQUEIRA, 2018), entre outros. Entretanto, o violão do oitocentos ainda não recebeu semelhante tratamento acadêmico.

Iniciaremos o percurso histórico musical ludovicense, considerando as mudanças organológicas a respeito do violão no oitocentos. Adiante, trataremos dos proprietários desses álbuns, fazendo uma análise do repertório. 


\section{Enquadramento histórico musical ludovicense}

Para compreendermos melhor a vida musical em São Luís no período em que a família do maranhense Domingos Feliciano Marques Perdigão (1808+1870), pai de Domingos Thomaz Vellez Perdigão (1842+1899), retornou de Portugal, em 1841, faremos um breve relato histórico do oitocentos no Maranhão, no qual os álbuns foram produzidos.

\subsection{A chegada da família Real}

Com as invasões napoleônicas a Portugal (1807-1810), a Coroa Portuguesa veio para o Brasil e fixou a capital da metrópole na colônia, de 1807 a 1821, na cidade do Rio de Janeiro. Esse é um período de rápidas modificações na cultura brasileira. Entre outras realizações do período está a contratação da missão artística francesa. Segundo o decreto de 12/08/1816 os franceses viriam ao Brasil para estabelecer a Escola Real de Ciências, Artes e Ofícios. Entre os integrantes da missão encontra-se o arquiteto Granjean de Montigny, os pintores Debret e Nicolas Tauny; Auguste Marie Taunay era o escultor; Simon Pradir era gravador; François Ovide engenheiro mecânico e o mestre de capela, organista e compositor Sigismund Neukomm. Além da Escola Real, foi criada a Biblioteca Real, a Academia de Belas Artes, o Jardim Botânico e o Teatro de São João. Na prática, foi uma mudança total de paradigmas para uma região que esteve fadada à exportação agrícola e ao extrativismo. Em poucas décadas, o Brasil formou uma elite cultural pela absorção dos costumes e ideais artístico culturais trazidos pela nobreza portuguesa. Outro fator determinante para essa virada cultural foi a Abertura dos Portos, que fomentou ainda mais as trocas culturais com países como Inglaterra, França e Itália.

Com a instalação da Corte Portuguesa no Brasil, Kiefer (1977) afirma que a música religiosa se desenvolveu ainda mais, pelos incentivos da realeza. Tal fato pode ter sido uma realidade local para o Rio de Janeiro, porém, não podemos esquecer-nos da enorme produção que tiveram, anteriormente, os compositores na Minas Gerais do século XVIII.

Os movimentos paralelos no Maranhão foram a fundação do Teatro União (1817), e a fundação da Biblioteca Estadual (1829). O Teatro União foi erguido com o dinheiro advindo das 
posses de dois importantes homens de negócios em São Luís, os portugueses Eleutério Lopes da Silva Varela, e Estevão Gonçalves Braga. O nome Teatro União foi uma homenagem à fundação do Reino Unido de Portugal, Brasil e Algarves (1815). O teatro foi adquirido pelo Estado, reformado e batizado, em 1852, com o nome de Teatro São Luís e, na década de 1920, recebeu o nome de Artbur de Azevedo (CARVALHO SOBRINHO, 2004, p. 14). Inclusive o espanhol Antonio Luiz Miró foi contratado pelo estado para dirigir uma série de espetáculos operísticos na reinauguração de 1852.

A partir da presença do Teatro União (1817), a música executada em festas religiosas nas igrejas desse período apresentava, além da secularização na sua estética oriunda da ópera, a influência da música italiana. Carvalho Sobrinho aponta o novo modelo adotado nas músicas compostas para as igrejas no seu livro A novena de Santa Filomena (1877), de Leocádio Rayol e complementa:

[...] É evidente que o surgimento de um novo modo de representação em uma esfera laica, a partir da fundação do Teatro São Luís, ameaçaria a unidade do centralismo católico em razão de uma estética humanista mais universal: a música teatral, seja de concerto, seja de caráter lírico. Entretanto, se houve alguma instabilidade circunstancial, não consegui extrair da crônica da época e nem do repertório ali preservado. O que transparece é a ampliação das práticas musicais para novos espaços e certa transformação no modelo composicional da música religiosa, agora sob a influência da ópera, com a utilização de uma orquestração mais grandiosa e passagens vocais fortemente influenciadas pela estética italiana (CARVALHO SOBRINHO, 2011, p. 13-14).

Esta citação enseja enfatizar-se a importância da ópera no gosto da sociedade ludovicense, o que é evidenciado na análise de repertório para violão dos álbuns da família Perdigão. No aspecto cultural, a vida musical, não somente do Maranhão, mas também em várias províncias brasileiras, o gosto pelo teatro, pela música de concerto, óperas e operetas levam o público a uma atividade social relevante, provavelmente como reprodução do modelo estabelecido pelo Império: "As temporadas de óperas tiveram início no período de D. João VI; praticamente datam de 1814. Os espetáculos costumavam ter lugar no Real Teatro de S. João que fora inaugurado em 1813” (KIEFER, 1977, p. 67).

A Abertura dos Portos, principalmente para negócios com a Inglaterra e a França, contribuiu para a criação de uma elite financeira cultural na capital, alicerçada na produção agrícola escravagista, de algodão a açúcar, e dos negócios na capital. A ópera e a música de salão bem como a música caseira se desenvolveram grandemente no Maranhão, desde cidades do interior, principalmente aquelas cidades beira rio como Caxias, Alcântara, Viana, Itapecuru, etc.: 
Esse modelo favoreceu um importante desenvolvimento cultural particularmente na capital portuária de São Luís, imortalizada na faustosa arquitetura dos sobrados e palacetes, nos ornamentos e arabescos das fachadas e dos azulejos portugueses e na singela beleza do espaço urbano e dos logradouros públicos que circundam o "Centro Velho", ou "Praia Grande”, num estilo urbanístico próprio e diferenciado. É o desencadeamento de uma prosperidade econômica cujo apogeu será atingido em meados do século XIX (CARVALHO SOBRINHO, 2004, p. 9).

Salomão (2015) cita uma lista de colégios maranhenses nos quais era ensinada música já na década de 1860. Entre eles, o Recolbimento de Nossa Senhora da Anunciação; Asilo de Santa Theresa; Colégio Nossa Senhora da Glória, Colégio Nossa Senhora da Soledade; Colégio Instituto de Humanidades; Colégio Sanct'Anna; Colégio Nossa Senhora de Nazareth; Colégio Nossa Senhora da Conceição; Colégio Episcopal Nossa Senhora dos Remédios; Colégio Perdigão; Colégio São João Batista e Internato e Externato de San'Paulo. No Almanak Administrativo, Mercantil e Industrial do Maranbão dos anos de 1861, 1863, 1866, 1868 e 1869 foram identificados vários colégios particulares e públicos que incluíam aulas de música em seu currículo, embora em alguns não de maneira permanente (SALOMÃO, 2017, p. 46). Destes, coincidentemente, os dois colégios Nossa Senhora dos Remédios e Colégio Perdigão, ambos fundados por Domingos Feliciano Marques Perdigão, ofereciam aulas de violão, entre outros instrumentos. Assim, desde a primeira metade do oitocentos, mas principalmente na segunda metade do século XIX, há uma enorme profusão no mercado da música e do violão, com vários anúncios de venda de instrumentos, cordas, métodos, música editada, papel para música, o que certamente abasteceu um número elevado de praticantes, profissionais e amadores.

\section{O Violão no Maranhão dos Oitocentos: questões organológicas}

\subsection{Primeira metade do século}

O presente trabalho não aborda questões sociais envolvidas na prática violonística do século XIX(LLANOS, 2016; TABORDA, 2011a/2011b), pois cremos que esta temática possa ter ocorrido de forma um tanto quanto diferenciada no caso da família Perdigão. Os fatores que atestam essa diferenciação com a maioria dos violonistas da São Luís oitocentista são os diversos deslocamentos da 
família entre Portugal e Brasil, além da educação do patriarca e de outros membros da família ter ocorrido em Coimbra. Dessa forma, o violão na família Perdigão teve influências distintas de uma maioria de praticantes ludovicenses, algo a ser discutido em trabalhos futuros onde fontes que representam essa diversidade possam ser contextualizadas.

A primeira questão a esclarecer quanto ao violão no Maranhão oitocentista é que, até cerca da metade do século XIX, este instrumento foi precedido por uma série de instrumentos de cordas dedilhadas, cuja alternância na nomenclatura representa um desafio à parte. Tal discussão não é o centro do presente trabalho, mas não pode passar despercebida.

A confusão terminológica parece sem solução definitiva, frente à grande família dos instrumentos de cordas dedilhadas. Budasz (2001) trata da problemática da nomenclatura desses instrumentos, em Portugal e no Brasil, entre o final do século XVII e meados do século XVIII. Ao se referir a um documento que descreve uma cena com uma "viola”, em Portugal do século XV, ele demonstra que, já naquela altura, a terminologia utilizada para designar esses instrumentos apresentava problemas:

Aquele instrumento era realmente uma viola dedilhada, o mesmo instrumento conhecido em outros tempos e lugares como guitarra? Confusão entre os termos parece ter existido já naquela data inicial [...] em meados do século XV, o termo viola, bem como vihuela e muitas variantes da palavra guitarra, foram usados para designar vários instrumentos de cordas - ambos de cordas dedilhadas e de corpo curvado. No século seguinte, o significado gradualmente se estreitaria para abranger apenas instrumentos com o corpo aproximadamente como uma figura de oito (BUDASZ, 2001, p. 10-11, tradução nossa) ${ }^{3}$.

Numa comparação com a documentação do Rio de Janeiro, em princípios do século XIX, o termo viola era amplamente utilizado, porém, ao longo das próximas décadas ocorreu uma diminuição nas ocorrências dessa denominação, sendo ela substituída, gradativamente, pelo termo violão. Para seu trabalho, Castro (2015) lançou mão de romances de época nos quais cenas da vida cotidiana dos instrumentistas era retratada: “[...] ainda que os romances não possam certificar a decadência da viola na cidade, percebe-se a progressiva diminuição de representações do instrumento

\footnotetext{
${ }^{3}$ Was that instrument really a plucked viola, the same instrument known in other times and places as guitar? Confusion between the terms seems to have existed already at that early date [...] by the mid-fifteenth century, the term viola, as well as vihuela and many variants of the word guitar, were used to designate several stringed instruments--both plucked and bowed. In the next century the meaning would gradually narrow to comprise only instruments with the body roughly in the shape of a figure eight
} 
e a concomitante ascendência do violão no decorrer do século XIX no Rio de Janeiro (CASTRO, 2015, p. 9).”

No caso do Maranhão, de forma análoga, ao longo da primeira metade do século XIX, a terminologia utilizada para designar instrumentos de corda dedilhada fez uso das denominaçóes viola; guitarra; guitarra francesa; violão francês e até mesmo viola francesa. Essa quantidade de denominaçóes pode ter surgido pela diversidade de instrumentos que conviveram num mesmo local, em um curto espaço de tempo. No segundo álbum (reg. 292/74) há uma prova desta mudança de nomes, pois, na Valsa (p.66) é inserida a denominação "Violão" e na Allemande (p.67) foi inserida a denominação “Guitarre”.

FIGURA 2 - Diferenças de denominações para o instrumento.

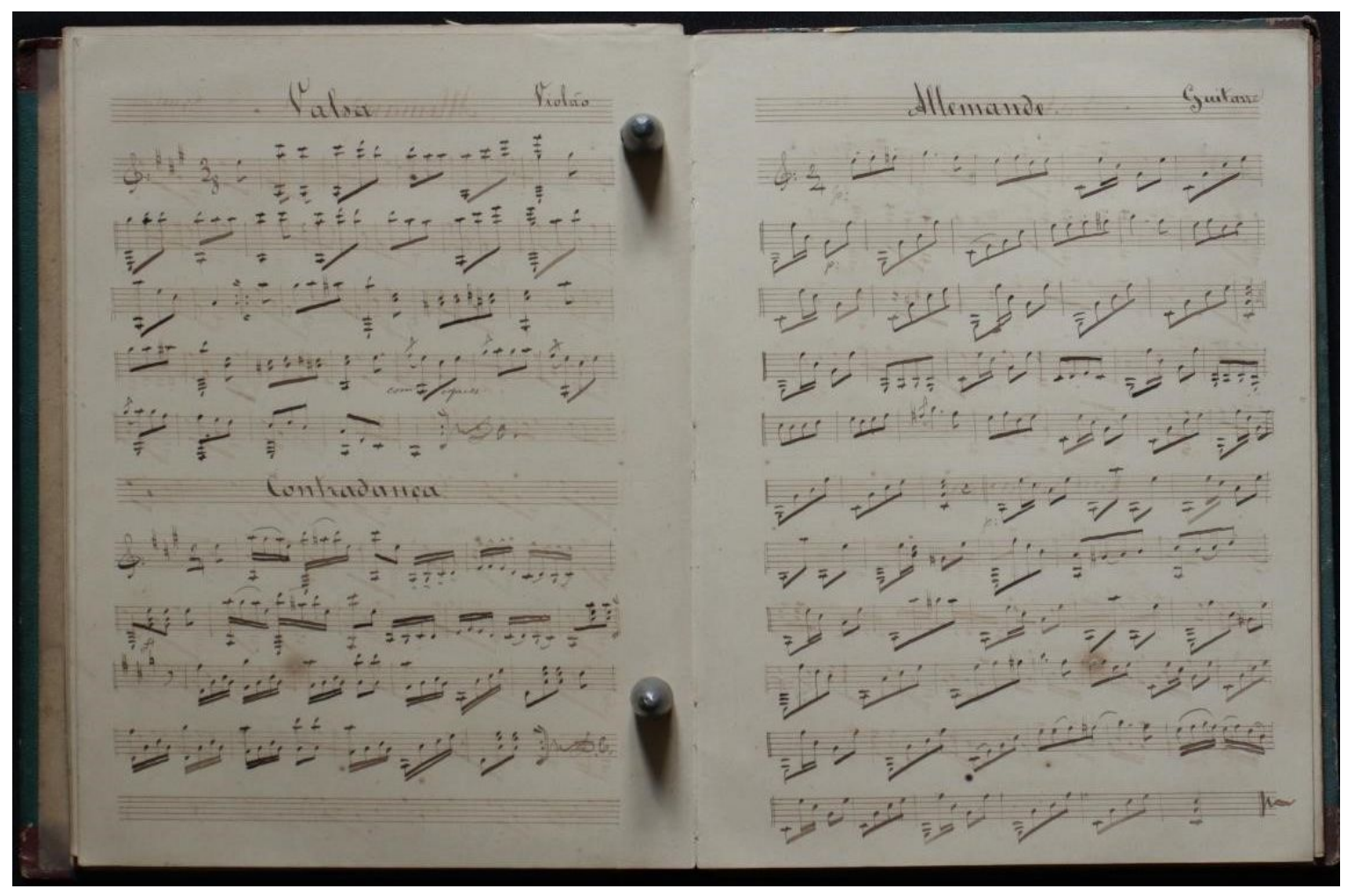

Fonte: Álbum de Música (pp. 66-67) reg. 292/74. Museu Histórico Artístico do Estado do Maranhão, 2018.

A primeira aparição do termo viola relacionado a instrumento de cordas dedilhadas ocorreu no jornal $A$ Bandurra, em 1828. Observemos que, na edição 0001, é citada uma série de instrumentos de corda dedilhada, não figurando entre eles o termo violão, antes sim, a viola. Já na edição 0005 do mesmo jornal, foi acrescentada a palavra guitarra entre os instrumentos. 
O Profeta Rei falando dos louvores ao Eterno diz no Psalmo 150 laudate eum in chordis.... que louvassem ao Altissimo em instrumentos de cordas, sem declarar se era Harpa, Viola, Cithara, ou Psalterio; ora sendo a BANDURRA instrumento de cordas, segue-se, que ao som delle se pódem cantar os mais altos obiectos.

Fontes: A Bandurra, 1828a; A Bandurra, 1828b.

No ano de 1830 um depoimento ao jornal Farol Maranhense nos confirma a noção de que os nomes de referência para instrumentos de cordas dedilhadas continuavam a ser a viola e a guitarra.

FIGURA 4 - Anúncio do jornal Farol Maranhense

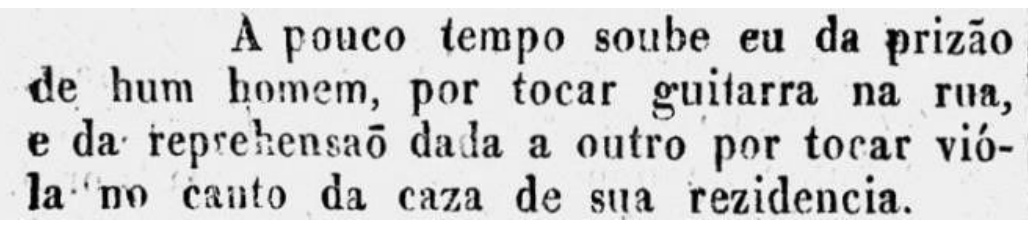

Fonte: Farol Maranhense, 1830, ed. 181.

\subsection{A terminologia na chegada da família Perdigão}

Aparentemente, só a partir da década de 1840 o termo violão foi lentamente inserido como uma possibilidade de se nominar o instrumento de cordas dedilhadas. Até mesmo no Colégio Nossa Senhora dos Remédios, fundado por Domingos Feliciano Marques Perdigão, a nomenclatura desses instrumentos parece ainda não estar totalmente consolidada. No espaço de cinco edições do mesmo jornal, a mesma instituição deu, ao instrumento, a denominação violão, na edição 184, e Viola Franceza, na edição 189. 


\section{FIGURA 5 - expressóes "violão" e "Viola Franceza"}

\begin{tabular}{|c|c|}
\hline $\begin{array}{l}\text { re } \\
\text { dude } \\
\text { offis } \\
\text { pia } \\
\text { of- } \\
\text { cu } \\
\text { rea. } \\
\text { eom }\end{array}$ & 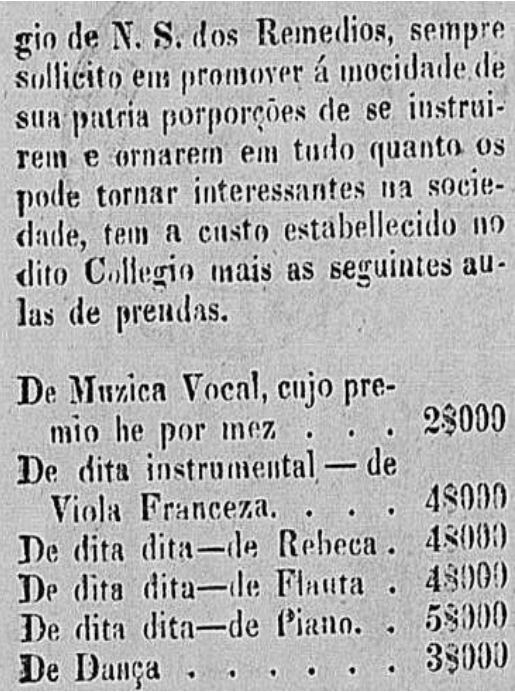 \\
\hline
\end{tabular}

Fontes: Publicador Maranhense, 1844a ed. 184; Publicador Maranhense, 1844b, ed. 189.

A hipótese que se estabelece é de que, até essa década, o violão era chamado de guitarra e, talvez, até mesmo de viola. No anúncio do Collegio N. S. dos Remedios do ano de 1847 é possível se ter uma noção da manutenção da confusão nos termos utilizados, pois as denominações "violão" ou "viola francesa” são utilizados para designar o mesmo instrumento:

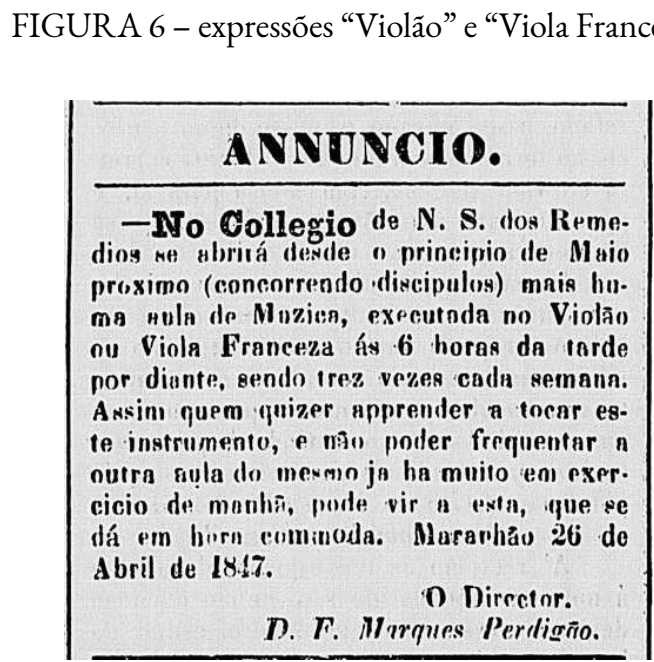

Fonte: Perdigão, 1847

O anúncio do jornal O Comercio (1843, ed. 0013) nos dá um testemunho da mudança de nomenclatura utilizada para designar o instrumento violão, em meados do século XIX. Como foi 
discorrido, até a década de 1840 a terminologia utilizada parece bem confusa, com citaçóes de viola, viola francesa, guitarra, guitarra francesa e até mesmo violão francês. Na verdade, como já explicitado, não há muitas formas de garantir a qual instrumento se estava referindo até esse momento. Porém, o anúncio (O COMERCIO, 1843) em que é citado um "methodo geral para violão" nos expõe que o termo violão estava fixando-se definitivamente. Aparentemente, um mesmo método foi vendido em Portugal e no Brasil, com uma mudança de nomenclatura. A denominação "viola franceza" do anúncio português foi substituída por "violão" no anúncio brasileiro. No anúncio brasileiro não consta o nome do autor do método, porém percebe-se que se trata do mesmo "Methodo Geral para Viola Franceza”, de Manuel Nunes Aguedo, do qual só encontramos a 2a edição, de 1856. Dada a extrema proximidade do texto, auferimos que a primeira edição é contemporânea ao anúncio no jornal maranhense (1841). A hipótese se confirma pelo texto da capa do método, que é praticamente o mesmo texto utilizado no anúncio, porém, trocando a expressão “a viola franceza” por "violão”.

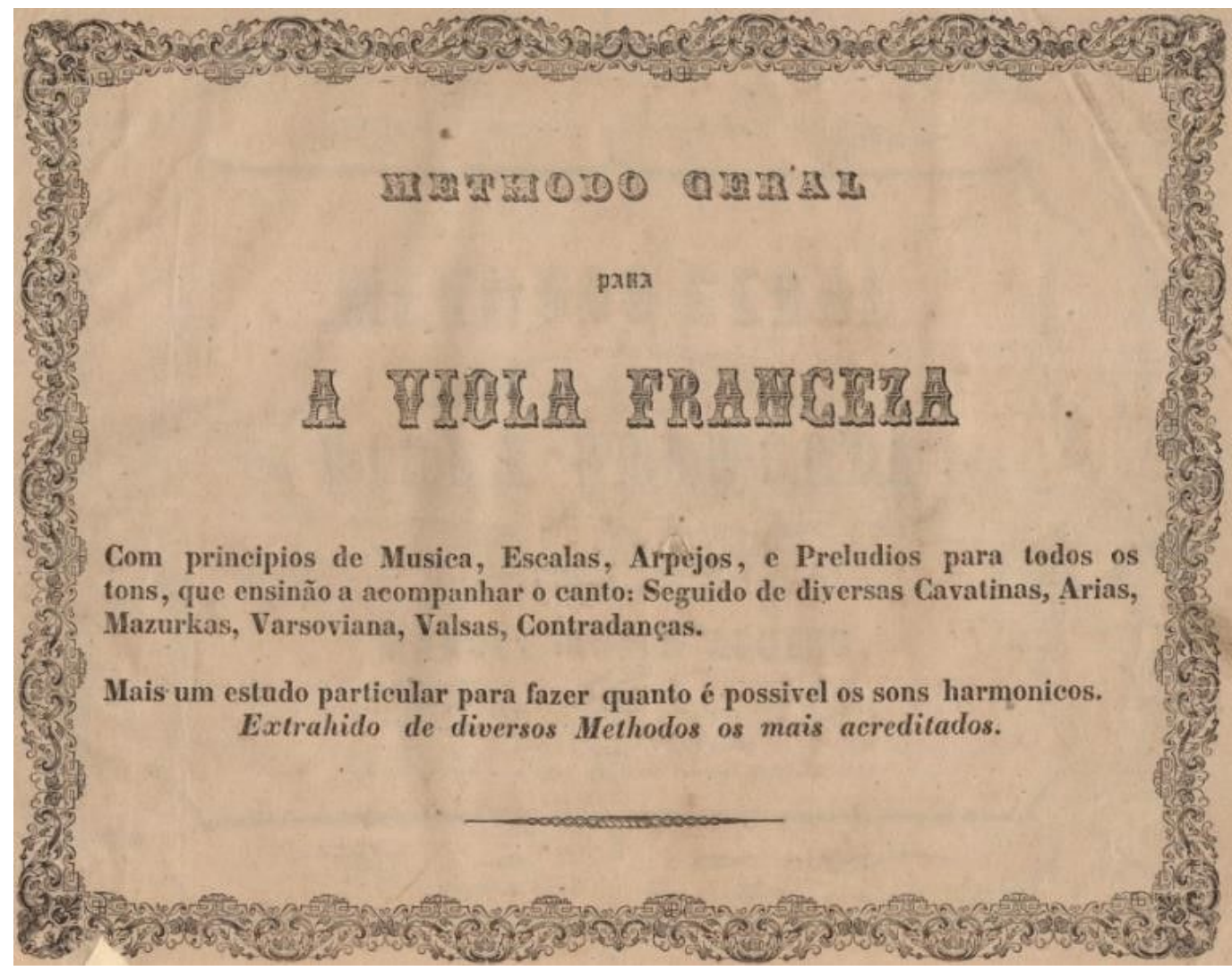

Fonte: Biblioteca Nacional de Portugal (m-2156-v). 
FIGURA 8 - Anúncio do Methodo Geral para Violão

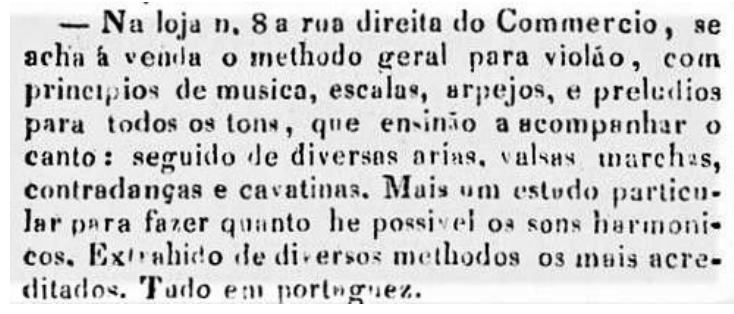

Fonte: O Comercio, 1843 ed. 0013.

Outra fonte de confusão pode ser encontrada entre os luthiers maranhenses da primeira metade de século XIX. Aparentemente, boa parte dos instrumentos era importada da Europa, porém uma pequena parte já começava a ser construída no Maranhão. No depoimento a seguir, José Alexandre de Araujo afirma ter sido o primeiro maranhense a produzir violas em São Luís, por volta de 1842. Ele demonstra que, no início da década de 40, seus instrumentos variavam muito de formato, podendo o mesmo instrumento ser classificado como uma viola ou mesmo um violão:

[...] me expuz a fazer uma viola [...] e não descansei em quanto não achasse uma [viola] Portuguesa para confrontal-a; porque o corpo era de meia regra e podia-se metter uma graduação de violão [...] não perdia o ânimo e sempre esperava que algum dia eu discobriria a sua regularidade, quero dizer a sua escalla” (ARAUJO, 1862, p. 1-3).

Porém, no momento em que ele deu seu testemunho, em 1862, o violão já estava satisfatoriamente diferenciado da viola. Inclusive, ele mesmo já diferenciava os violóes portugueses dos franceses dessa época, afirmando que o segundo era muito sensível: “[...] se tivesse posses pra mandar vir pinho de Veneza, faia própria para Rabeca, e violão [...] e sua construção a maneira portuguesa que é bem conhecida a sua segurança, enquanto que os violóes franceses são de muito fraca segurança [...]”. (ARAUJO, 1862, p. 1-3).

Entre as décadas de 1840/50 parece ter havido alguma normalização no nome do instrumento violão em São Luís, e é exatamente nessa década e nesse local que nasceu Domingos Thomas Vellez Perdigão. De qualquer forma, isso não significa que, a partir desse momento, não houvesse mais confusão terminológica, porém, alcançou-se certa regularidade na utilização do termo violão. Como veremos, os álbuns da família Perdigão trazem tanto os termos guitarra quanto violão para denominar o mesmo instrumento, mesmo tendo-se admitido que os álbuns tenham recebido peças para o instrumento somente a partir de 1860. 


\section{O primeiro álbum - reg. $291 / 74$}

Inicialmente, quando nos deparamos com os álbuns de música que estão no MHAM, a informação era de que tais documentos pertenciam a "Domingos Perdigão". Pode parecer fácil relacionar autor e obra, porém, neste caso, a informação foi bastante problemática. Somente uma análise mais aprofundada da biografia da família Perdigão, aliada a um exame in loco nos permitiu entender autoria e linhas de custódia dos álbuns.

Ocorre que os ditos álbuns tiveram não um, senão três Domingos Perdigão como proprietários, sendo eles o pai, filho e neto. O primeiro deles é Domingos Feliciano Marques Perdigão (1808+1870); o segundo é o seu filho, Domingos Thomaz Vellez Perdigão $(1842+1899)$; o terceiro é seu neto, Domingos de Castro Perdigão $(1872+1929)$. Como último proprietário dos álbuns, Fernando Eugênio dos Reis Perdigão (1908+1990) doou os documentos ao MHAM em 1974. De fato, as quatro gerações mantiveram os álbuns por motivos de utilidade e recordação, pois todos eram músicos amadores.

Para a compreensão da estimativa do início da produção do primeiro álbum (reg. 291/74), fazemos uso da declaração do frontispício do Hymno, de Raimundo José Marinho, anteriormente abordado por Cerqueira (2016):

FIGURA 9 - Frontispício do Hymno (reg. 291/74, p. 42)

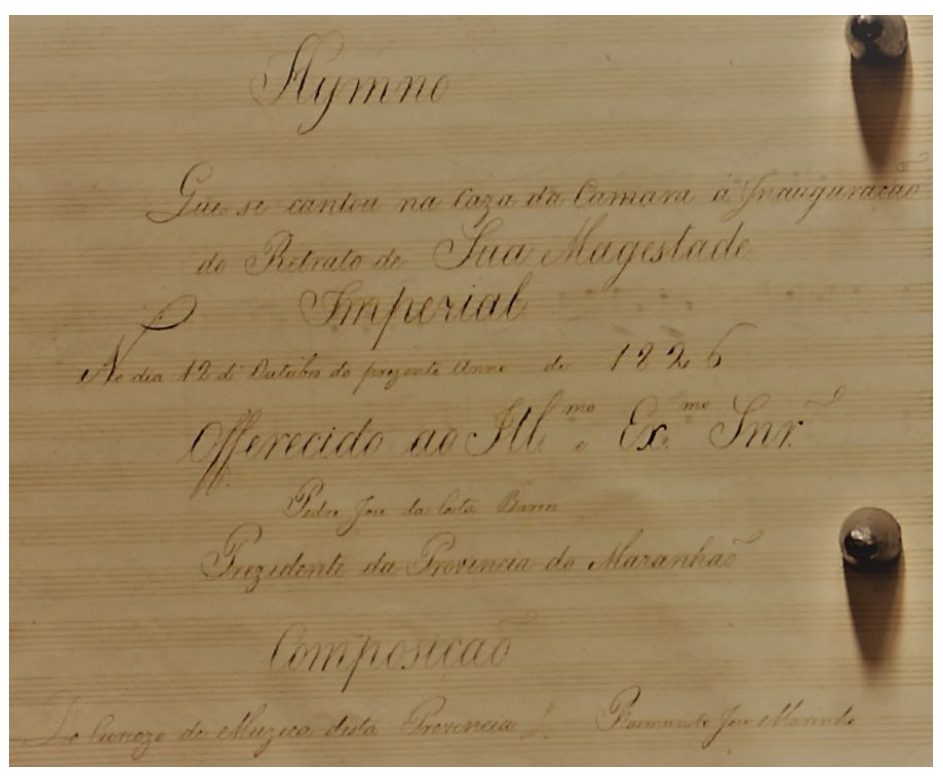

Fonte: Álbum de Música (reg. 291/74). Museu Histórico Artístico do Estado do Maranhão, 2018. 
A inscrição: “[...] no dia 12 de Outubro do prezente ano de 1826 [...]” corrobora a hipótese de que essa fonte tenha sido produzida no ano de 1826. No entanto, esse não é um fato isolado em si, pois, outras constataçốes são feitas a respeito do aspecto temporal deste álbum. A sua caligrafia; fatores de organologia musical; o uso de claves; sua tinta, bem como o seu repertório até o próximo marco temporal o aproximam muito do seu primeiro utilizador: Domingos Feliciano Marques Perdigão $(1808+1870)$.

Os dois álbuns contêm, a priori, duas grafias bem distintas, o que demarca a alteração da sua custódia. O repertório da parte inicial do primeiro álbum (reg. 291/74), correspondendo a 2/3 (199 páginas), é formado por peças para voz e acompanhamento, sendo 8 delas para canto e Piano e 9 para canto e Piano Forte. O fato do seu primeiro utilizador inserir as denominaçóes Piano e Piano Forte para designar o mesmo instrumento demonstra mais uma evidência de que o álbum foi iniciado na primeira metade do século XIX. A última terça parte deste álbum, com 39 páginas, é dedicada completamente a peças para violão, marcando sua custódia por seu segundo utilizador.

É bem possível que o material para a confecção do primeiro álbum tenha sido adquirido em Portugal, entre 1815 e 1820, pela superioridade de seu papel, pois o papel ora vendido no Brasil era de inferior qualidade. Isto se confirma na verificação da baixa qualidade do segundo álbum, produzido a partir de 1869. Dessa forma, o primeiro álbum (reg. 291/74) foi iniciado em data anterior à data do Hymno, de 1826, haja visto que esta peça é a terceira a figurar nesse álbum. Este Hymno já havia sido estudado por Cerqueira (2016), e hoje a pesquisa já trouxe novos resultados para a discussão ali iniciada.

Em 1841, quatro anos após sua formatura na Universidade de Coimbra, Domingos Feliciano Marques Perdigão retornou para São Luís e fundou o Colégio Nossa Senhora dos Remédios, foi o primeiro colégio regular de instrução desta capital. 
FIGURA 10 - Chegada da família Perdigão

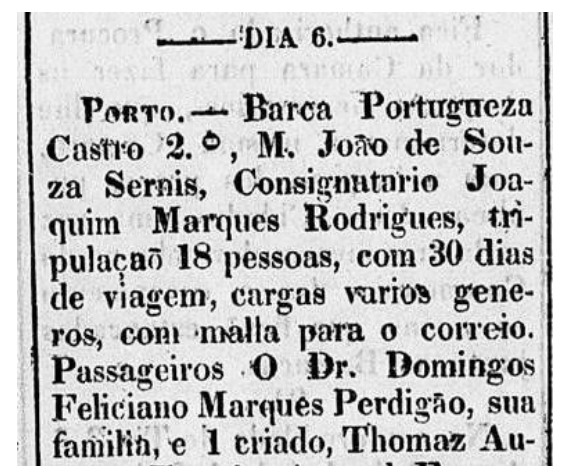

Fonte: Jornal Maranhense, 1841.

O próprio fundador ministrava aulas de música vocal e solfejo, o que é mais um fator que corrobora a sua participação na primeira parte do primeiro álbum (reg. 291/74). Vicente Ferrer de Lira (ca.1796+1857), músico português, que atuava como mestre-de-capela e organista da Catedral do Maranhão, foi também um dos professores de música no colégio (PERDIGÃO, 1845). Um ano após a fundação do Colégio N. S. dos Remédios, em 1842, nasceu Domingos Thomaz Vellez Perdigão, em São Luís do Maranhão.

O colégio foi progredindo no cenário do ensino maranhense à medida que eram acrescentadas mais disciplinas e, no ano de 1854, ocorreu um fato que o diferenciou substancialmente dos demais colégios. Seu proprietário, Domingos Feliciano Marques Perdigão foi nomeado professor de história sagrada e eclesiástica no Seminário Episcopal de Santo Antônio. A partir desse momento, o Colégio N. S. dos Remédios passou a ser também preparatório para o Seminário, onde seus alunos seiam aceitos, após a conclusão dos estudos. Inclusive, o colégio mudou seu nome para Colégio Episcopal Nossa Senhora dos Remédios:

Em 1854, Domingos Feliciano foi nomeado professor do Seminário Episcopal do Maranhão, e os exames prestados no Colégio dos Remédios eram aceitos como preparatório para o Seminário. Assim, a sua instituição chamou-se Colégio Episcopal de Nossa Senhora dos Remédios (SALOMÃO, 2015, p. 140).

No ano de 1858, Domingos Feliciano Marques Perdigão retornou a Portugal para tratar de doença. Segundo notícia publicada, sua saúde achava-se "arruinada". Assim sendo, ele deixou a direção do Colégio Episcopal Nossa Senhora dos Remédios e a cadeira de história sagrada e eclesiástica 
do Colégio Episcopal de Santo Antônio. A notícia expõe ainda que Perdigão levou consigo parte da numerosa família, deixando três dos seus filhos menores, internos no Colégio Episcopal N. S. dos Remédios. Ele permaneceu em Portugal por oito anos (Publicador Maranhense, 1858, ed. 0074), levando consigo o filho, Domingos Thomas Vellez Perdigão.

Foi nesse ano em que ocorreu outro importante marco temporal no primeiro álbum (reg. 291/74). Trata-se da "Preghiera” com confirmação de copista "R.H.S.", oferecida ao filho do proprietário do primeiro álbum, "Domingos Thomaz Velez Perdigão”. O sobrenome Vellez grafado faltando a letra " $L$ " demonstra que o copista era uma pessoa de fora da família, porém, não nos foi possível detectar a autoridade da cópia por terem sido inscritas apenas suas iniciais.

Em mais duas peças além desta, figura a "Cöplet” oferecida ao "Exmo Sro Miguel Antonio de Souza Vascolcellos e Horta, de Sancta Comba Dão" do compositor “Macedo”. Provavelmente, a pessoa à qual foi oferecido o Cöplet trata-se, na verdade, de Miguel António de Sousa Horta Almeida e Vasconcelos (1831+1891), o “segundo Barão” de Santa Comba Dão. Ele tinha relações fortes com a região onde os Perdigão permaneceram de 1858 a 1866. A inscrição desta peça demonstra também que o repertório do álbum tem estreita relação com o cotidiano da família.

Aparentemente, essas duas peças demarcam temporalmente o fim da fase em que o primeiro álbum esteve com o seu primeiro proprietário/produtor, Domingos Feliciano Marques Perdigão. Elas demonstram que o álbum passou a custódia de seu filho, Domingos Thomaz Vellez Perdigão, que na altura da dedicatória da "Preghiera" estava com seu pai, em Portugal, com a idade de 17 anos. Uma idade suficiente para iniciar a escrita de peças no álbum. Foi o que ocorreu, pois, a quinta peça após essa dedicatória inicia a série de 29 peças para violão com a grafia do seu novo utilizador, e que tomou conta de todas as últimas 39 páginas no primeiro álbum, sequência essa retomada no início do segundo álbum (reg. 292/74).

Em 1866, Domingos Feliciano Marques Perdigão e sua família retornaram para São Luís. Segundo notícia abaixo (Figura 11), estava com a saúde "quasi restabelecida”. Não lhe foi permitido retomar o antigo cargo de professor do Colégio Episcopal Nossa Senhora dos Remédios, pois o diretor que havia assumido seu antigo colégio não aceitou restituir-lhe mais a direção do mesmo e, portanto, ele fundou o Colégio Perdigão. 
FIGURA 11 - Retorno de Domingos Feliciano Marques Perdigão

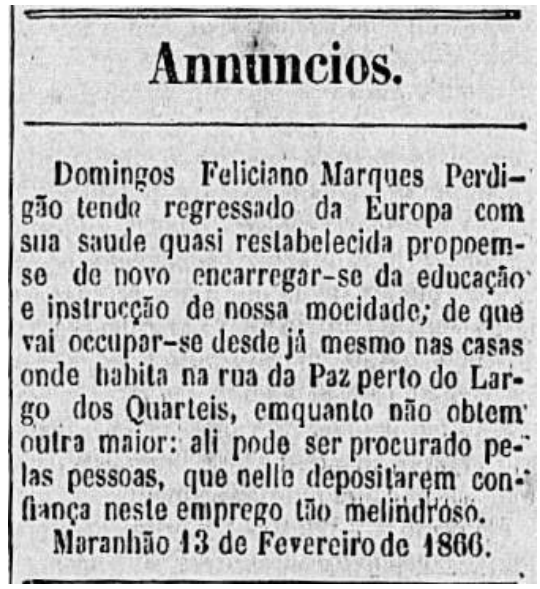

Fonte: A Situação, 1866 ed. 138

Segundo Salomão (2015, p. 49), o colégio oferecia ensino de rabeca, violão, flauta e clarinete em 1868, sendo acrescida a aula de cantoria e piano em 1869. O Colégio Perdigão teve, então, como um dos professores de música o próprio Domingos Thomaz Vellez Perdigão, além do professor de violino (rabeca) e violão, Francisco Xavier Bekman, que também foi professor, pela maior parte da década de 60, no Colégio Episcopal Nossa Senhora dos Remédios. Apesar da continuidade do álbum ter recebido 29 peças para violão das mãos do segundo utilizador, não foi ele quem ministrou aulas do instrumento no Colégio Perdigão.

\subsection{0 segundo álbum - reg. $292 / 74$}

Os anos de 1869/70 marcaram profundamente a vida de Domingos Thomaz Vellez Perdigão e são ponto-chave para a presente pesquisa, pela complexidade dos fatos ocorridos em tão pouco tempo. Em 1869 ele publicou os Princípios Elementares de Música em 10 Lições (PERDIGÃO, 1869), que era um método de teoria musical direcionado aos seus alunos do Colégio Perdigão. Nesse mesmo ano morreu Francisco Xavier Bekman, a quem havia declarado ser, no método supracitado, "meu mestre de música”, que revisou e aumentou o método. Esse é o mesmo ano em que ele iniciou o segundo álbum (reg. 292/74) no qual estão registradas algumas dúzias de peças para violão solo, entre outras. 
FIGURA 12 - Contracapa do segundo álbum - reg. 292/74

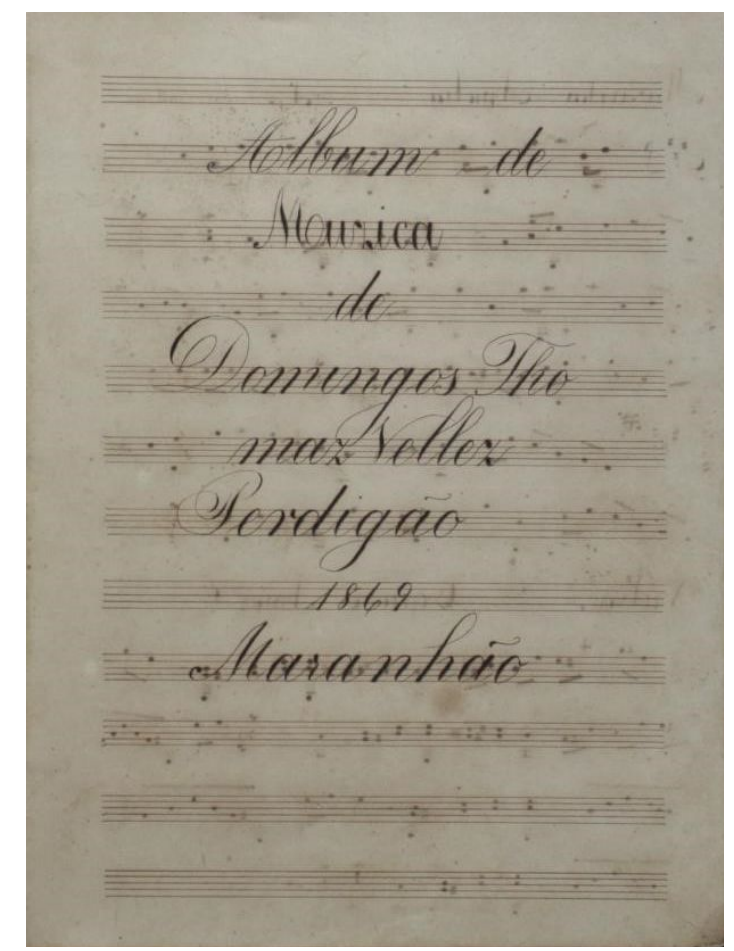

Fonte: Museu Histórico Artístico do Estado do Maranhão, 2018

No ano seguinte, em 1870, e, talvez pela mesma doença que o acometeu desde 1858, morreulhe o pai, Domingos Feliciano Marques Perdigão. Com sua morte, são encerradas as atividades do Colégio Perdigão. Essas mudanças repentinas tiveram repercussões importantes na vida de Domingos Thomaz Vellez Perdigão. A partir desse momento, sua vida deu uma guinada ao ramo da Indústria e Comércio, mesmo sem ter deixado de dar aulas particulares de rabeca, como é visto em anúncios de 1870 e 1874. Porém, seu envolvimento como industrial parece ter crescido a cada ano: "Observa-se também que nos anos de 1872 e 1873, tanto o Colégio Perdigão quanto o da Nossa Senhora dos Remédios não aparecem mais na lista [de aulas de instrumento], dois anos após a morte do fundador de ambos, Domingos Feliciano Marques Perdigão” (SALOMÃO, 2015, p. 47).

Em 1872 nasceu seu filho, Domingos Castro Perdigão $(1872+1929)$, que foi o terceiro utilizador dos álbuns da família, a partir de 1899. Em 1874 Domingos Thomaz Vellez Perdigão dissolveu a sociedade (Vellez \& C.) que mantinha com José Maria Soares Vieira (PERDIGÃO; VIEIRA, 1874), mesmo ano em que figurou como secretário da Festa Popular do Trabalho. Em 1878, Domingos participou da Exposição Industrial do Maranhão (O PAIZ, 1878, p. 3, ed. 0012). Finalmente, no ramo que permaneceu até os últimos anos de sua vida, Domingos Thomaz Vellez 
Perdigão ganhou diversos prêmios em exposiçốes industriais por durante toda a década de 70/80, produzindo vinhos, conservas, licores e óleos. Seus produtos mais apreciados eram o vinho de caju e as conservas de frutas.

Na década de 1880, Domingos Thomaz Vellez Perdigão se transferiu para Portugal, onde passou a produzir vinhos e conservas de frutas até o seu falecimento, em 1899. Ao que tudo indica, seu filho, Domingos de Castro Perdigão vai a Portugal e traz consigo, entre outros documentos, os álbuns e uma partitura fora do álbum, datada de 1889.

FIGURA 13 - Viagem de Domingos de Castro Perdigão

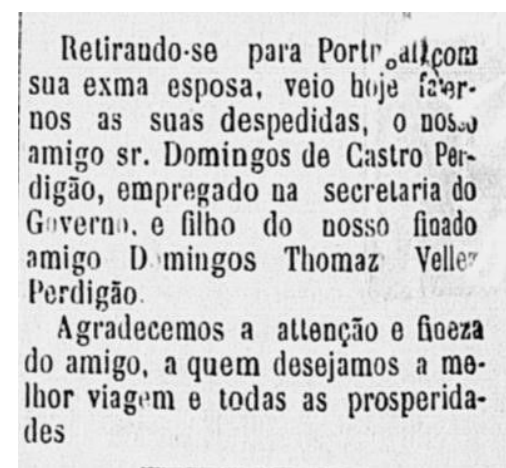

Fonte: Diário do Maranhão, 1899

Essa partitura demonstra que o segundo álbum foi completado por volta de 1889, quando seu pai começou a escrever música fora do álbum, em folhas soltas. Portanto, essa partitura é também um importante marco temporal na produção dos álbuns de música da família, demarcando o fim da sua produção, dez anos antes do falecimento do seu segundo utilizador.

O terceiro utilizador dos álbuns foi Domingos de Castro Perdigão, flautista amador. É muito provável que os álbuns tenham sido uma espécie de lembrança dos familiares, e que ele ainda os tenha utilizado para tocar suas melodias. Ele teve uma vida de grande participação junto aos órgãos públicos, como escritor; como presidente da Feira da Indústria Maranhense; como fundador das faculdades de Farmácia e Direito (1918); Fundador do Instituto Histórico e Geográfico do Maranbão (IHGM), em 1925; e como diretor da Biblioteca Pública - atual Biblioteca Benedito Leite.

Uma série de fatos demonstra que Domingos de Castro permaneceu com os álbuns por cerca de 25 anos, antes de transmiti-los ao filho, Fernando Eugênio dos Reis Perdigão. Para tal, descrevemos os fatos, conforme eles nos foram apresentados. 
Os álbuns foram doados por Fernando Eugênio dos Reis Perdigão ao Museu Histórico Artístico do Maranhão, em 1974, conforme Livro de Tombo da instituição (MARANHÃO, 1974). Porém, além dos dois álbuns, foram doadas também algumas partituras manuscritas e impressas. Entre elas, a Vivo Polka (reg. 300/74), datada de 1889 e com a caligrafia de Domingos Thomaz Vellez Perdigão, contribuiu muito para a compreensão do término da produção do segundo álbum, bem como a apropriação/custódia desses álbuns e de outros documentos por Domingos de Castro Perdigão, no ano de 1899.

Essa música tem a caligrafia de Domingos Thomaz Vellez Perdigão, que morou em Portugal entre 1883 e 1899 . Este fato revela que manteve sua atividade musical caseira, mesmo nos anos em que residiu em Portugal, e que os álbuns permaneceram consigo até o final de sua vida, em 1899. Seu filho, Domingos de Castro Perdigão, residiu em São Luís por toda a vida. Na época em que seu pai se transferiu para Portugal, Domingos de Castro tinha apenas 11 anos, cedo demais para obter a posse dos álbuns.

Com a morte do pai, Domingos de Castro Perdigão foi a Portugal para vender a propriedade da família, oportunidade em que trouxe para São Luís - como recordação e mesmo para a sua prática musical - os álbuns e os manuscritos, além de outros documentos que foram divididos entre os demais membros da família Perdigão.

Outro fato que aponta para essa recolha de documentos em Portugal, após a morte de seu pai, é uma doação de Domingos de Castro Perdigão à “Secção de autographos” da Biblioteca Pública do Estado, em 1901, logo após sua viagem a Portugal. Trata-se do método autógrafo de seu pai, do ano de 1869, e que permaneceu com ele em Portugal, até os seus últimos dias.

FIGURA 14 - Anúncio da doação dos Principios de Musica (PERDIGÃO, 1969)

\section{Secção ile autographos.}

Para esta seccão, inangurada com a doação leita pelo sr. Domingos de Castro Perdigão, do autographo dos-Principios de musica-, de Domingos Thomaz Vellez Perdigão, entrou durante 0 anno findo o do poemeto-Mais Murdos-, de Theophilo Braga, publicado no Rio, por occasião do 4." eentenario do descobrimento do Brazil, e editado pelo sr. Fran Paxeco, que o offereceu a esta Bibliotheca.

Fonte: Mensagens do Governador do Maranhão para Assembléia, 1901, ed.00001 
Tanto Domingos de Castro Perdigão quanto o filho, Fernando Eugênio dos Reis Perdigão, foram músicos amadores. O primeiro tocava flauta transversa; e o segundo, violino. Pelo fato de os álbuns terem sido doados por Fernando Perdigão ao $M H A M$, se supõe que eles tenham passado para a sua custódia pela década de 1920. Fernando Eugênio dos Reis Perdigão (1908+1990) foi advogado, escritor, membro da Academia Maranhense de Letras e professor de Direito. Em 1970 se transferiu para o Rio de Janeiro onde trabalhou como advogado nos Diários Associados. Ele chegou a fazer uma série de apresentações tocando violino, acompanhado ao piano por Eder Santos, porém nunca foi músico profissional, atuando mais na música doméstica, como documentado na imagem abaixo:

FIGURA 15 -Domingos de Castro Perdigão (flauta), Fernando Eugênio dos Reis Perdigão (violino) e família (ca.1925)

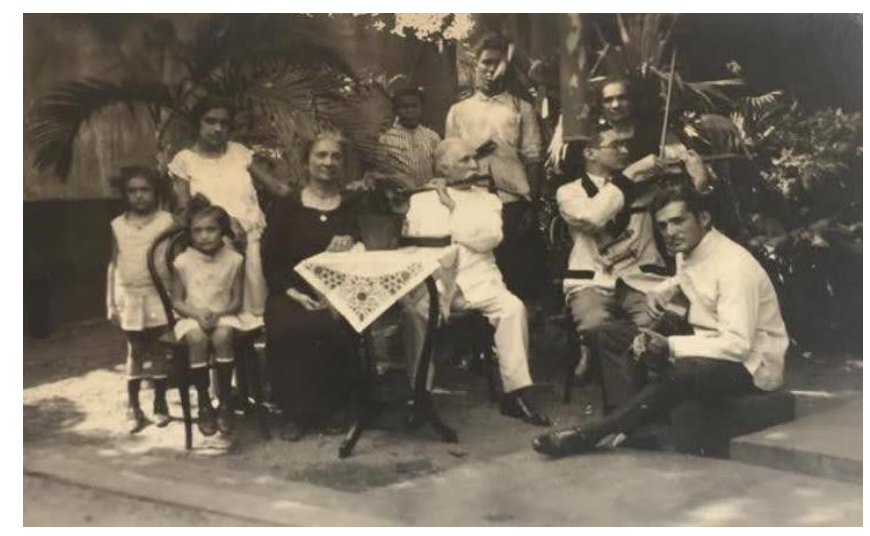

Fonte: acervo da família Perdigão

Fernando Perdigão teria deixado a mulher e os filhos em São Luís, para que completassem o calendário escolar de 1970 e para que ele organizasse a nova residência, no Rio de Janeiro.

As atuais quinta e a sexta geraçôes da família Perdigão finalmente se profissionalizaram no ramo da música. Filha de Fernando Eugênio dos Reis Perdigão, a compositora e multi-instrumentista Ignez Eleonora Morais Perdigão (1954) nasceu em São Luís e foi, com a família, para a capital Rio de Janeiro, em 1972. Ela é professora, arranjadora, regente, e tem sua atuação ligada ao choro e ao samba, tendo gravado com diversos nomes da MPB, como Cristina Buarque, Velha-Guarda da Portela, Mário Lago, Wilson Moreira, Walter Alfaiate, Mauro Duarte, entre outros. Seus filhos, Matias Correa (arranjador, canto, contrabaixo e Chapman Stick), Mariana Bernardes (compositora, professora, canto, cavaquinho e violão) e Alice Passos (arranjo, canto, flauta, violão, professora) seguem a linhagem de músicos da família Perdigão, e mantêm em sua custódia partes do acervo histórico da 
família Perdigão, como a flauta de Domingos de Castro Perdigão e o violino de Fernando Eugênio dos Reis Perdigão.

\section{2 Análise contextual do repertório}

Como apresentação do conteúdo dos dois álbuns, foram feitas duas tabelas com informaçôes preliminares, fruto do exame das fontes, auxiliado por uma busca em outras fontes, complementares. Esses resultados não são definitivos, mas podem auxiliar futuras pesquisas.

TABELA 1 - Primeiro álbum (reg. 291/74)

\begin{tabular}{|c|c|c|c|c|}
\hline \multicolumn{2}{|c|}{ Título - transcrição diplomática } & \multirow{2}{*}{$\begin{array}{l}\text { Autor - transcrição } \\
\text { diplomática } \\
\text { N. C. [Luigi Ricci } \\
\text { 1805-1859] }\end{array}$} & \multirow{2}{*}{$\begin{array}{l}\text { Instrumentação } \\
\text { voz e piano forte }\end{array}$} & \multirow{2}{*}{$\frac{\text { Página }}{1-12}$} \\
\hline 1. & $\begin{array}{l}\text { Cavatina -Noi mirate in si bel giorno - } \\
\text { hiara de Rosenberg }\end{array}$ & & & \\
\hline $\begin{array}{l}2 . \\
{[\mathrm{Os} \mathrm{Ca}]}\end{array}$ & $\begin{array}{l}\text { Cavatina da Opera Montechios e Capuletos } \\
\text { puletos e os Montecchio] }\end{array}$ & Vincenzo & voz e piano forte & $13-24$ \\
\hline 3. & Hymno Brasileiro & Raimo José Marinho & vos e piano & $25-29$ \\
\hline 4. & Hymno Brazileiro (Ca.1831) & José de Lima & voz e piano forte & $30-33$ \\
\hline 5. & Hymno Brasileiro & D. Pedro Primeiro & $\begin{array}{l}\text { Canto, violinos, } \\
\text { Basso }\end{array}$ & $34-41$ \\
\hline $\begin{array}{l}6 . \\
\text { Maranh }\end{array}$ & $\begin{array}{l}\text { Hymno ao Presidente da Província do } \\
\text { âo }\end{array}$ & $\begin{array}{l}\text { Raimundo José } \\
\text { Marinho }\end{array}$ & $\begin{array}{l}\text { Trompas; Clarinetas; } \\
\text { Violinos; Sopranos; } \\
\text { Basso }\end{array}$ & $42-51$ \\
\hline $\begin{array}{l}7 . \\
\text { Siviglia }\end{array}$ & Cavatina Una voce poco fa - Barbieri de & Gioachino Rossini & voz e piano forte & $53-67$ \\
\hline 8. & la mizencia & N.C. & voz e piano & $68-70$ \\
\hline 9. & Le Troubadour du Tage, romance & $\begin{array}{l}\text { N. C. [Jean Joseph } \\
\text { Benoît Pollet (1755- } \\
\text { 1823)] }\end{array}$ & voz e piano & $71-72$ \\
\hline 10. & Cavatina cantata da velluto Nil Andronico & $\begin{array}{l}\text { Mercadante } \\
\text { [Giuseppe Saverio } \\
\text { Raffaele Mercadante } \\
(1795-1870) \text { ] }\end{array}$ & voz e piano & $73-78$ \\
\hline 11. & Fugindo d'aldeia & $\begin{array}{l}\text { N.C. [Schiopeta, } \\
\text { Domingos] }\end{array}$ & voz e piano & $79-86$ \\
\hline 12. & Himno Patriotico & N. C. & voz e piano forte & $87-93$ \\
\hline 13. & Ondas Clamarão & N.C. & voz e piano forte & $95-103$ \\
\hline
\end{tabular}


TABELA 1 - (cont.) Primeiro álbum (reg. 291/74)

\begin{tabular}{|c|c|c|c|c|}
\hline \multicolumn{2}{|c|}{ Título - transcrição diplomática } & \multirow{2}{*}{$\begin{array}{l}\begin{array}{l}\text { Autor - transcrição } \\
\text { diplomática }\end{array} \\
\text { Schiopeta, } \\
\text { Domingos [(1820- } \\
\text { 1837)] }\end{array}$} & \multirow{2}{*}{$\begin{array}{l}\text { Instrumentação } \\
\text { voz e piano }\end{array}$} & \multirow{2}{*}{$\begin{array}{c}\text { Página } \\
104-108\end{array}$} \\
\hline 14. & A Saudade me Flagela & & & \\
\hline 15. & Se o meu bem não se apressa & N.C. & voz e piano-forte & $109-112$ \\
\hline 16. & Stride la vampa nel trovadore [trovatore] & $\begin{array}{l}\text { N. C. [Giuseppe } \\
\text { Verdi] }\end{array}$ & voz e piano & $113-120$ \\
\hline 17. & Doetto per Due soprani & N.C. & voz e piano & $121-126$ \\
\hline \multicolumn{4}{|c|}{ Anna Bolena } & $127-139$ \\
\hline 19. & Cavatina nell Opera Semiramide & Gioachino Rossini & voz e piano & $140-161$ \\
\hline 20. & Preghiera & N.C. & coral e piano & $162-167$ \\
\hline 21. & Choro & N.C. & 4 vozes & $168-178$ \\
\hline 22. & Cöplet & N.C. & Voz e piano & $179-185$ \\
\hline 23. & Lanceiros de Garibaldi & N.C. & $\begin{array}{l}2 \text { flautas; } 2 \text { clarinetes; } \\
2 \text { trompas; Figle }\end{array}$ & $186-197$ \\
\hline 24. & Lanceiros & N.C. & violino & $198-199$ \\
\hline 25. & Polka Lulu & N.C. & violão & 200 \\
\hline 26. & Mazurka Amelia & N.C. & violão & 200 \\
\hline 27. & Valsa & N. C & violão & 201 \\
\hline 28. & Valsa & N.C. & violão & 201 \\
\hline 29. & Thema variado & N.C. & violão & 201-203 \\
\hline 30. & Graças a Deos [Drama em 5 atos] & $\begin{array}{l}\text { N. C. [Antonio } \\
\text { Ribas] }\end{array}$ & violão & 203 \\
\hline 31. & Miserere do Trovador & $\begin{array}{l}\text { N. C. [Giuseppe } \\
\text { Verdi] }\end{array}$ & violão & 204 \\
\hline 32. & Amelia - Mazurca & N.C. & violão & 205 \\
\hline 33. & Valsa Alemãa & N.C. & violão & $205-206$ \\
\hline 34. & Chorado & N.C. & violão & 206 \\
\hline 35. & Il Trovatore coro di Zingarella & $\begin{array}{l}\text { N. C. [Giuseppe } \\
\text { Verdi] }\end{array}$ & violão & $207-208$ \\
\hline 36. & La Vampa [Il Trovatore: "Stride la vampa"] & $\begin{array}{l}\text { N. C. [Giuseppe } \\
\text { Verdi] }\end{array}$ & violão & $209-210$ \\
\hline $\begin{array}{l}37 . \\
\text { Lam }\end{array}$ & $\begin{array}{l}\text { Aria final da Lucci de lamermoor [Lúcia de } \\
\text { 1oor] }\end{array}$ & $\begin{array}{l}\text { N. C. [Gaetano } \\
\text { Donizetti] }\end{array}$ & violão & $211-213$ \\
\hline $\begin{array}{l}38 . \\
\text { Oper } \\
39 .\end{array}$ & $\begin{array}{l}\text { Nel cor mi suono un grido, Cavatina da } \\
\text { [Cavatina da Opera Gemma di Vergi] }\end{array}$ & $\begin{array}{l}\text { N. C. [Gaetano } \\
\text { Donizetti] }\end{array}$ & violão & $213-215$ \\
\hline 40. & Polka Americana & N.C. & violão & $215-216$ \\
\hline
\end{tabular}


TABELA 1 - (cont.) Primeiro álbum (reg. 291/74)

\begin{tabular}{|c|c|c|c|c|}
\hline \multicolumn{2}{|c|}{ Título - transcrição diplomática } & \multirow{2}{*}{$\begin{array}{l}\text { Autor - transcrição } \\
\text { diplomática } \\
\text { n.c. }\end{array}$} & \multirow{2}{*}{$\begin{array}{l}\text { Instrumentação } \\
\text { violão }\end{array}$} & \multirow{2}{*}{$\frac{\text { Página }}{216-218}$} \\
\hline 41. & "Contradanças Provinciaes" & & & \\
\hline $\begin{array}{l}42 . \\
\text { Verdi }\end{array}$ & Romanza n'el Opera Trovatore de maestro & $\begin{array}{l}\text { Verdi [Giuseppe } \\
\text { Verdi] }\end{array}$ & violão & 218 \\
\hline 43. & Valsa & N.C. & violão & $219-220$ \\
\hline 44. & Polka La Boemia & N. C. & violão & 220 \\
\hline 45. & N.C. & N.C. & violão & 221 \\
\hline 46. & Schotisch & N.C. & violão & $222-223$ \\
\hline 47. & Mazurk & N. C. & violão & $223-224$ \\
\hline 48. & Fandango Saloio & $\begin{array}{l}\text { N. C. [música/dança } \\
\text { tradicional } \\
\text { portuguesa] }\end{array}$ & violão & $224-226$ \\
\hline 49. & Muzica do beijo & N.C. & violão & $226-227$ \\
\hline 50. & Valsa Hespanhola & N.C. & violão & $228-229$ \\
\hline 51. & Valsa & N.C. & violão & $229-230$ \\
\hline $\begin{array}{l}52 . \\
\text { di Tenda }\end{array}$ & Oh! Divina Agnese. Aria nel Opera Beatrice & $\begin{array}{l}\text { N. C. [Vincenzo } \\
\text { Bellini] }\end{array}$ & violão & $231-233$ \\
\hline 53. & Quadrilha de Contradanças & $\begin{array}{l}\text { N. C. [Théodore } \\
\text { Barrière et Lambert } \\
\text { Thiboust] }\end{array}$ & violão & $233-238$ \\
\hline $\begin{array}{l}54 . \\
\text { comedia }\end{array}$ & $\begin{array}{l}\text { Cavatina de Simplicio da paixão, na } \\
\text { Velha namorada. - muzica do maestro Miró }\end{array}$ & $\begin{array}{l}\text { Francisco Xavier } \\
\text { Pereira da Silva, } \\
\text { música de Luiz Miró }\end{array}$ & violão & 239 \\
\hline
\end{tabular}

Fonte: Álbum de Música (reg. 291/74). Museu Histórico Artístico do Estado do Maranhão

O repertório dos álbuns corrobora a localização temporal e física de seus produtores. Ele é formado por peças de autores contemporâneos locais e de outros estados, além de uma série de compositores europeus, cujo repertório transitava por teatros do Brasil e de Portugal. Destacam-se os 21 arranjos de árias e cavatinas de óperas de autores europeus contemporâneos à produção dos álbuns, como João António Ribas (1799+1870); Vincenzo Bellini (1805+1835); Gaetano Donizetti (1797+1848); Giuseppe Verdi (1813+1901); Gioachino Rossini (1792+1868); Giuseppe Mercadante $(1795+1870)$ e Jules Massenet $(1942+1912)$.

Quanto aos autores contemporâneos maranhenses, ou que residiram no Maranhão, a Mazurka Amelia (reg. 292/74, p.1) é atribuída a Antonio de Freitas Ribeiro. Ele foi professor de flauta, violão, rabeca e violoncelo, além de dirigir orquestras para bailes e soirées em São Luís da 
segunda metade do século XIX. O maranhense Sergio Augusto Marinho figura como compositor do Hymno (reg. 291/74, p. 25), já anteriormente abordado por Cerqueira (2016). Flautista, Sérgio foi um dos primeiros músicos maranhenses a figurar como compositor. Foi professor de música na Casa dos Educandos Artífices durante a segunda metade do século XIX. Regeu bandas e a orquestra do Teatro São Luiz. A Valsa (reg. 292/74, p. 46) é atribuída ao músico maranhense Bernardino Rego Barros que, além de maestro, era professor de clarineta e flauta, copista, vendia partituras, e afinava pianos. O arranjo do Himno de Li (reg. 292/74, p. 122) é atribuído a João Evangelista do Livramento. Ele foi compositor, pianista e violonista, que também afinava e vendia pianos na São Luís da segunda metade dos oitocentos.

Autor da música de Cavatina de Simplicio da paixão, na comedia Velha namorada, o espanhol Antonio Luis Miró atuou na primeira metade do século XIX em Portugal como compositor de óperas e operetas cômicas. Em 1850 se estabeleceu em São Luís como diretor do Teatro São Luiz. Ele foi professor de piano, arranjador e vendedor de partituras. Em 1851 compôs a Novena de Nossa Senhora dos Remédios.

Entre autores de outros Estados brasileiros, o paraense Theodoro Orestes, autor da Valsa de Theodoro Orestes (reg. 292/74, p. 12), foi professor de música, compositor, arranjador de música para teatro. O carioca Januário da Silva Arvellos, autor de Quando eu morrer, ninguém chore a minha morte (reg. 292/74, p. 47) foi um dos compositores mais populares do Segundo Império. Seu pai, com nome homônimo (de origem espanhola), foi professor de D. Pedro I.

TABELA 2 - Segundo Álbum (reg. 292/74)

\begin{tabular}{clll}
\hline Título - transcrição diplomática & Autor - transcrição diplomática & Instrumentação & Página \\
\hline 1. O que é Amor?; & Antonio de Freitas Ribeiro & Violão & $1-1$ \\
2. Mazurka Amelia & & violão & \\
3. Graça de Deus; & [João Antonio Ribas] & Violão & $2-2$ \\
4. Amor Perfeito & N.C. & violão & \\
5. Coro da Opera Sonnambula & Vicenzo Bellini & violão & 3 \\
6. Comédia-drama militar "29 Ou & [ROMANO, José, 1825-1887] & violão & 4 \\
& & & \\
\hline
\end{tabular}

\footnotetext{
${ }^{4}$ As informações entre chaves foram adicionadas pelos pesquisadores e estão sujeitas à averiguação.
} 
TABELA 2 - (cont.) Segundo Álbum (reg. 292/74)

\begin{tabular}{|c|c|c|c|}
\hline Título - transcrição diplomática & Autor - transcrição diplomática & Instrumentação & Página \\
\hline 7. Valsa [c/ variações] & N.C. & violáo & $5-6$ \\
\hline 8. Valsa de Fernando Carulli & Fernando Carulli & violão & 6 \\
\hline 9. Miserere do Trovador & N. C. [Giuseppe Verdi] & violão & 7 \\
\hline 10. Amelia & Sergio Augusto Marinho & violão & 8 \\
\hline \multirow{2}{*}{$\begin{array}{l}\text { 11. Valsa da Rainha Victoria; } \\
\text { 12. A madrugada }\end{array}$} & N.C. & Violão & \multirow[t]{2}{*}{$9-9$} \\
\hline & N.C. & violão & \\
\hline $\begin{array}{l}\text { 13. Don Cesar de Bazan - ópera cômica } \\
\text { em } 3 \text { atos }\end{array}$ & [Jules Massenet] & violão & 10 \\
\hline 14. Thema variado & N.C & violão & $10-12$ \\
\hline 15. Valsa de Theodoro Orestes & Theodoro Orestes - maestro no Pará & violão & 12 \\
\hline 16. Dueto da Opera Lucrezia Borgia & Gaetano Donizetti $(1797+1848)$ & violão & $13-14$ \\
\hline 17. Josephina & N.C. & N.C. & 15 \\
\hline 18. Valsa & N.C. & Piano & $16-17$ \\
\hline 19. Thema com variaçóes & N.C. & violão & $17-20$ \\
\hline 20. Os Homens do ar & $\begin{array}{l}\text { [POUZADOUX, Claude. Contos e } \\
\text { lendas da mitologia grega?] }\end{array}$ & N.C. & 20 \\
\hline 21. Suonata per Chitarra a solo & Antonio Giácomo Monzino & violão & $12-27$ \\
\hline 22. Mazurk & Francisco Libanio Colás & violino & $27-28$ \\
\hline 23. Schotisch & N. C. & violino & 29 \\
\hline 24. Polka & Bernardino R. Barros & N.C. & 30 \\
\hline 25. Himno do Normal Theatro & D. Perdigão[?] & violino & 31 \\
\hline 26. Himno de Valladolid & N. C. & violino & 32 \\
\hline 27. Himno de Cristina & N. C. & violino & $33-34$ \\
\hline 28. Valsa & N.C. & Piano & 35 \\
\hline 29. Valsa & N. C. & voz e violão & $36-38$ \\
\hline 30. Balada do Rochedo & Francisco Anto de Carrvo & voz e piano & $39-40$ \\
\hline 31. Himno Nacional & Francisco Manuel da Silva & violino & $40-41$ \\
\hline 32. Schotisch & N.C. & violino & $41-42$ \\
\hline 33. Himno Nacional & Francisco Manuel da Silva & N.C. & $43-44$ \\
\hline 34. Mazurk & $\begin{array}{l}\text { J.Z.F. Parga [Joaquim Zeferino } \\
\text { Ferreira Parga (ca.1834-1907)] }\end{array}$ & N.C. & 44 \\
\hline 35. Himno de 1826 & N.C. & violino & 45 \\
\hline 36. Valsa & Bernardino Rego Barros & violão & 46 \\
\hline
\end{tabular}


TABELA 2 - (cont.) Segundo Álbum (reg. 292/74)

\begin{tabular}{|c|c|c|c|}
\hline Título - transcrição diplomática & Autor - transcrição diplomática & Instrumentação & Página \\
\hline $\begin{array}{l}\text { 37. [Quando eu morrer, ninguém chore } \\
\text { a minha morte] }\end{array}$ & N. C. [Januário da Silva Arvellos] & voz violão & $47-48$ \\
\hline 38. Polka & Francisco Xavier Bekman & N.C. & 49 \\
\hline 39. Quadrilha de contradanças & Francisco Libânio Colás & N.C. & $50-52$ \\
\hline 40. Quadrilha da Opera Ernani & N. C. [Giuseppe Verdi] & violino & $53-55$ \\
\hline 41. Contradanças Vizeence & N. C. & violino & 55 \\
\hline 42. Himno Maranhense & $\begin{array}{l}\text { N. C. [Antonio Claro dos Reis } \\
\text { Rayol] }\end{array}$ & violino & 56 \\
\hline 43. Quadrilha & Sergio A. Marinho & violino & $57-59$ \\
\hline 44. Vizeence & N.C. & N.C. & $59-60$ \\
\hline 45. Orphée aux enfers & N. C. [Jacques Offenbach] & violino & $61-63$ \\
\hline 46. Valsa & N. C. & violáo & 64 \\
\hline 47. Mazurk & N.C & violáo & 64 \\
\hline 48. Valsa & N.C. & violão & 65 \\
\hline 49. Contradança & N. C. & violão & 65 \\
\hline 50. Allemande & N. C. & violão & 66 \\
\hline 51. Valsa & N.C. & violão & 67 \\
\hline 52. Valsa & N.C. & violão & 68 \\
\hline 53. N.C. & N. C. & canto e Piano & $69-73$ \\
\hline 54. Polka & N. C. & N.C. & 73 \\
\hline 55. N.C. & N. C. & Guitarra Inglesa & 74 \\
\hline 56. Quadrilha & N. C. & violino & $75-77$ \\
\hline 57. Schotisch & N. C. & violino & $77-78$ \\
\hline 58. Mazurka & N. C. & violino & 78 \\
\hline 59. Valsa Ingleza & N. C. & N.C. & 79 \\
\hline 60. Lanceiros & N. C. & violino & $80-81$ \\
\hline 61. O Principe Imperial & N. C. & violino & $82-84$ \\
\hline $\begin{array}{l}\text { 62. Os Estudantes do Recife - Quadrilha } \\
\text { Franceza }\end{array}$ & Francisco Libânio Colás & violino & $85-87$ \\
\hline $\begin{array}{l}\text { 63. A Cigana de Paris - Quadrilha } \\
\text { Franceza }\end{array}$ & B. Rego Barros & violino & $88-90$ \\
\hline 64. Marcha Fúnebre & N.C. & violino & 90 \\
\hline 65. N.C. & N.C. & $\begin{array}{l}\text { melodia com } \\
\text { letra }\end{array}$ & 91 \\
\hline
\end{tabular}


TABELA 2 - (cont.) Segundo Álbum (reg. 292/74)

\begin{tabular}{|c|c|c|c|}
\hline Título - transcrição diplomática & Autor - transcrição diplomática & Instrumentação & Página \\
\hline 66. Lanceiros & Faustino da Cruz Rebelo & N.C. & $92-94$ \\
\hline 67. Miosotys, Valsa & L. Raiol [Leocádio Rayol] & N.C. & 95 \\
\hline 68. Violeta & L. Raiol [Leocádio Rayol] & violino & 96 \\
\hline 69. Quadrilha Lundum & N. C. & N.C. & $97-100$ \\
\hline 70. N.C. & N.C. & $\begin{array}{l}\text { melodia com } \\
\text { letra }\end{array}$ & $\begin{array}{l}101- \\
103\end{array}$ \\
\hline 71. Música do Drama Graça de Deos & $\begin{array}{l}\text { N. C. [João António Ribas } \\
(1799+1870)]\end{array}$ & violão & $\begin{array}{l}104- \\
118\end{array}$ \\
\hline 72. Mazurk & N. C. & violão & 118 \\
\hline 73. Thema & N.C, & violão & 118 \\
\hline 74. Simpatia & I. Pereira & violão & 119 \\
\hline 75. Quadrilha da Opera Trovador & N. C. [Giuseppe Verdi] & violão & $\begin{array}{l}120- \\
122\end{array}$ \\
\hline 76. Himno de Li & arr. Evangelista & violão & 122 \\
\hline 77. Contradamça da familia Morel & N.C. & violão & 123 \\
\hline 78. Lulú & N.C. & violão & $\begin{array}{l}123- \\
124\end{array}$ \\
\hline 79. Mazurk & N.C. & violão & 124 \\
\hline 80. Ária da Opera Sonambula - Gavolta & N. C. [Antonio Luiz Miró] & violão & $\begin{array}{l}125- \\
126\end{array}$ \\
\hline 81. Solo Inglez & N.C. & violão & 127 \\
\hline 82. Thema com variações & N.C. & violão & $\begin{array}{l}127- \\
129\end{array}$ \\
\hline $\begin{array}{l}\text { 83. Eco il pegno, Cavatina da Opera } \\
\text { Gemma di Vergi [Gemma di Vergy, } \\
\text { 1834] }\end{array}$ & N. C. [Gaetano Donizetti] & violão & $\begin{array}{l}129- \\
131\end{array}$ \\
\hline 84. A Vivandeira - ballet & $\begin{array}{l}\text { N. C. Arthur Saint-Léon } \\
(1815+1870) \text { [melodia açoreana sec. } \\
\text { XIX] }\end{array}$ & violão & 131 \\
\hline
\end{tabular}

Fonte: Álbum de Música (reg. 292/74). Museu Histórico Artístico do Estado do Maranhão

\section{Considerações finais}

Os álbuns de música da família Perdigão contêm uma importante parcela do repertório maranhense para o violão do período imperial (1822/1889). No presente estudo, demonstramos uma 
variedade de ferramentas com o intuito de revelar o histórico da produção dos álbuns, bem como o histórico de seus produtores/utilizadores, além do histórico de seu arquivamento. Para tal, fizemos uso de questôes como a organologia musical, as biografias de seus utilizadores, a análise in loco da caligrafia, uso de tintas, e o estudo do seu repertório.

A biografia dos seus proprietários foi um instrumento investigativo de extrema importância, revelando nomes, datas e locais de produção/custódia dos mesmos, além de questôes como a jornada musical de seus produtores/utilizadores. Também, através da análise in loco dos álbuns, foi possível estabelecer uma relação temporal da sua produção por questões de organologia musical, em que as expressóes piano forte e guitarra foram utilizadas para designar o piano e o violão, dada a variedade de expressôes utilizadas ao longo do século XIX para se designar principalmente instrumentos de cordas dedilhadas como o violão, que veio a se estabelecer somente na segunda metade do século.

A análise da caligrafia foi determinante para estabelecer o percurso musical dos dois primeiros proprietários dos álbuns, bem como o momento em que o primeiro álbum foi transmitido ao seu segundo utilizador/produtor, Domingos Thomaz Vellez Perdigão. Outros marcos temporais como o Hymno (p. 25) ao início do primeiro álbum; a Preghiera, na sua quarta seção, bem como a data da contracapa do segundo álbum (reg. 292/74) e a partitura avulsa da música Vivo Polka (reg. 300/74) foram determinantes para a compreensão da trajetória dos álbuns e de seus utilizadores.

Por último, e não menos importante, a análise do repertório corrobora as afirmações de que os álbuns foram produzidos com o repertório ora vigente tanto no Maranhão quanto em Portugal, por terem sido as localidades onde seus produtores se estabeleceram.

A presente pesquisa acadêmica chama a atenção para a urgente necessidade de um estudo mais aprofundado acerca da utilização dos álbuns na música doméstica ludovicense, bem como um estudo da biografia da família Perdigão, pois, não fosse o apreço de seus descendentes pela sua história, provavelmente não teríamos hoje acesso aos álbuns que foram transmitidos de pai para filho por quatro geraçóes, num período de, aproximadamente, 145 anos 


\section{REFERÊNCIAS}

ALVES, Z. (org.). Choros Maranhenses: caderno de partituras. São Luís: BNB Cultural, 2012. BUDASZ, Rogério. The Five-Course Guitar (Viola) in Portugal and Brazil in the late seventeenth and early eighteenth centuries. A dissertation presented to the Faculty of Graduates School University of Southern California in partial Fulfillment of the requirements for the Degree Doctor Of Philosophy, august, 2001.

CABEZAS BOLAÑOS, Esteban. La organización de archivos musicales marco conceptual. In: Información, Cultura y Sociedad, 2005, n. 13, pp. 81-99.

CARVALHO SOBRINHO, J. B. Acervo João Mobana: uma contribuição bistórico-documental à pesquisa musical. In: CONGRESSO NACIONAL DA ANPPOM, 14, 2003, Porto Alegre. Anais... Porto Alegre: UFRGS, 2003a. p. 1-8.

. A Música Religiosa de Leocádio Rayol (1849-1909) e sua Relação

com o Maranbão do Século XIX: um estudo musicológico, com transcrição, análise e perspectiva histórica. Tese (Doutorado em Música) - PPGMUS, UFRGS, Porto Alegre, 2003b.

. A Música no Maranhão Imperial: um estudo sobre o compositor

Leocádio Rayol baseado em dois manuscritos do Inventário João Mohana. In: Em Pauta, Porto Alegre, v. 15, n. 25, julho a dezembro 2004.

. Texto e contexto: a comédia musical Uma Véspera de Reis de Francisco

Libânio Colás (São Luís, 1830 - Recife, 1885) Teresina: EDUFPI, 2010. . Música Sacra em São Luis: A Novena de Santa Filomena (1877) de

Leocádio Rayol. Teresina: EDUFPI, 2011.

CASTRO, Renato Moreira Varoni de. Musical artefacts in literary texts: the viola in nineteenthcentury Rio de Janeiro. Opus, Porto Alegre, v. 21, n. 1, p. 9-42, jun. 2015.

CERQUEIRA, Daniel Lemos. Uma edição diplomática do Hymno (1826) de Raimundo José Marinho. In: DEBATES. UNIRIO, n. 17, p.137-171, nov. 2016. . 'Acervo João Mohana' do Arquivo Público do Estado Do Maranbão

(APEM): algumas observações. Revista Música, v. 18, n. 1, São Paulo, p. 210-255, 2018. . O Piano no Maranbão: uma pesquisa artística. Tese (Doutorado em Música) - PPGM, UNIRIO, Rio de Janeiro, 2019.

COSTA NETO, R. J. M. E tem choro no Maranhão? Subsidios históricos e musicológicos para um processo de formação do choro no Maranhão entre final do séc. XIX e meados do séc. XX. Dissertação (Mestrado em Música) - PPGMUS, UFMG, Belo Horizonte, 2015.

DANTAS FILHO, Alberto. O acervo musical João Mobana e a vida musical litúrgica no Maranhão imperial - o "romantismo de província" como reprodução do ornamentalismo begemónico na Ilba de São Luis (1836 - 1892). Tese de doutoramento. Universidade Nova de Lisboa, 2006.

DUARTE, Fernando. L. S. Resgates e Abandonos do Passado na Prática Musical Litúrgica Católica 
no Brasil entre os Pontificados de Pio Xe Bento XVI(1903-2013). Tese (Doutorado em Música) PPGMUS, UNESP, São Paulo, 2016.

FERREIRA, A. N. A. A Escola Lilah Lisboa de Araújo: O ensino de música no Nordeste e no Maranhão. São Luís: EDUFMA, 2017.

GOUVEIA NETO, João Costa. Ao som de Pianos, Flautas e Rabecas...Estudo das vivências musicais das elites na São Luis da segunda metade do século XIX. Dissertação de Mestrado apresentada à Coordenação do Programa de Pós-Graduação em História do Brasil, do Centro de Ciências Humanas e Letras da Universidade Federal do Piauí. Teresina, 2010.

KIEFER, Bruno. História da música brasileira: dos primórdios ao início do século XX. Porto Alegre: Movimento, 1977.

LLANOS, Carlos Fernando Elias, Violão e Identidade Nacional: A "Moral" do Instrumento. In: Revista Tulha, v. 2, n 2, p.227-250. Ribeirão Preto, 2016.

MARANHÃO. Secretaria de Estado da Cultura. Museu Histórico Artístico do Estado do Maranhão. Livro de Tombo. Reg. 291 e 292, p. 156, 1974.

MILLAR, Laura Agnes. A morte dos fundos e a ressurreição da proveniência: o contexto arquivistico no espaço e no tempo. In: Informação Arquivística, Rio de Janeiro, v. 4, n. 1, p. 144-162, jan./jun., 2015.

MOHANA, João. A grande música do Maranhão. 2ae ed. Ver. aum. São Luís: Ediçôes SECMA, 1995.

PASCOA, M. L. F. R. Ópera em Manaus. Manaus: Valer Editora, 2009.

PERDIGÃO, Domingos Thomaz Vellez. Princípios elementares de música em 10 lições. São Luís: Typographia do Frias, 1869.

SALOMÃO, Káthia. O Ensino de Música no Maranbão (1860-1912): uma ênfase nos livros escolares de Domingos Thomaz Vellez Perdigão e Antonio Claro dos Reis Rayol. Dissertação de Pós-Graduação em Educação. UFMA, São Luís, 2015.

, O ensino de música no Maranbão (1860-1912): lugares, práticas elivros

escolares. São Luís: EDUFMA, 2017.

SANTOS, D. F.; SANTOS, E. G. A Música Militar do Maranbão: uma abordagem histórica e as iniciativas da Banda do Corpo de Bombeiros em prol das Bandas Maranhenses. Musifal, v. 4, Maceió, p. 49-65, 2019.

SANTOS NETO, J. A. Ladainha de Antonio Rayol: Ladainha Pequena. Monografia (Especialização em Musicologia) - Curso de Especialização em Musicologia, CCE, UFPI, 2009.

SANTOS, R. A. Música Popular Maranbense e a questão da identidade cultural regional.

Dissertação (Mestrado em Cultura e Sociedade) - PGCult, UFMA, São Luís, 2012.

SILVA, Paula Figueirêdo. Uma História do Piano - em São Luís do Maranhão. Edufma, 2015.

TABORDA, Marcia. Violão e identidade nacional: Rio de Janeiro 1830-1930. Rio de Janeiro:

Civilização Brasileira, 2011a. 
- Da viola à viola grande: a trajetória do violão no século XIX. In. LOPES, Antonio Herculano; ABREU, Martha; ULHÔA, Martha Tupinambá de; VELLOSO, Monica Pimenta. (Orgs.). Música e história no longo século XIX. Rio de Janeiro: Fundação Casa de Rui Barbosa, 2011b.

\section{Referências Hemerográficas}

A BANDURRA. Declaraçôes preliminares, p. 4., ed. 0001. São Luís, 15 de janeiro de 1828 a. Disponível em:

http://memoria.bn.br/DocReader/DocReader.aspx?bib=749478\&Pesq=Harpa,\%20Viola,\%20Cit hara\&pagfis=1. Acesso em 08/10/2020. Indicação, p. 168, ed. 0005. São Luís, 23 de março de 1828b. Disponível em: http://memoria.bn.br/DocReader/DocReader.aspx?bib=749478\&Pesq=Harpa,\%20Viola,\%20Cit hara\&pagfis=169. Acesso em 08/10/2020.

ARAUJO, Jose Alexandre de. O Artista, p. 1-3, ed. 18. São Luís, 27 de setembro de 1862. Disponível em:

http://memoria.bn.br/DocReader/docreader.aspx?bib=234281\&pasta=ano\%20186\&pesq=me\%20 expuz\%20a\%20fazer\%20uma\%20viola\&pagfis=62. Acesso em 08/10/2020.

A SITUAÇÃO. Annuncios. p. 4, ed. 138. São Luís, 1o de março de 1866. Disponível em:

http://memoria.bn.br/DocReader/docreader.aspx?bib $=761338 \&$ pasta $=$ ano\%20186\&pesq=\%22D omingos\%20Feliciano\%20Marques\%20Perdig\%C3\%A3o\%22\&pagfis=538. Acesso em 08/10/2020.

DIÁRIO DO MARANHÃO. Annuncios, p. 2, ed. 07831. São Luís, 7 de outubro de 1899.

Disponível em:

http://memoria.bn.br/DocReader/docreader.aspx?bib=720011\&pasta=ano\%20189\&pesq=Domi ngos\%20de\%20Castro\&pagfis=31403. Acesso em 08/10/2020.

FAROL MARANHENSE. Variedades, p. 774, ed. 181. São Luís, 02 de março de 1830. Disponível em:

http://memoria.bn.br/DocReader/docreader.aspx?bib=749958\&pasta=ano\%20183\&pesq=por\%2 0tocar\%20guitarra\%20na\%20rua\&pagf is=938. Acesso em 08/10/2020.

JORNAL MARANHENSE. Movimento do Porto, p. 4, ed. 0001. São Luís, 09 de julho de 1841. Disponível em:

http://memoria.bn.br/DocReader/docreader.aspx?bib=749451\&pasta=ano\%20184\&pesq=\%22Fel iciano\%20Marques\%20Perdig\%C3\%A3o\%22\&pagfis=4. Acesso em 08/10/2020.

MENSAGENS DO GOVERNADOR PARA ASSEMBLEIA. Secção de Autographos, p. 39, ed.00001. São Luís, 13 de fevereiro de 1901. Disponível em:

http://memoria.bn.br/DocReader/docreader.aspx?bib=873039\&pasta=ano\%20190\&pesq=sec $\% \mathrm{C}$ 3\%A7\%C3\%A3o\%20de\%20autographos\&pagfis=1247. Acesso em 08/10/2020.

O COMÉRCIO. Annuncios, p. 4, ed. 0013. São Luís, 17 de janeiro de 1843. Disponível em: http://memoria.bn.br/DocReader/docreader.aspx?bib=719110\&pasta=ano\%20184\&pesq=princi 
pios\%20de\%20musica,\%20escalas\&pagfis=56. Acesso em 08/10/2020.

PUBLICADOR MARANHENSE. Annuncios, p. 4, ed. 184. São Luís, 05 de junho de $1844 a$. Disponível em:

http://memoria.bn.br/DocReader/docreader.aspx?bib=720089\&pasta=ano\%20184\&pesq=violao \%20e\%20trompa\&pagfis $=723$. Acesso em 08/10/2020. Annuncios, p. 4, ed. 189. São Luís, 18 de maio de 1844 b.

Disponível em:

http://memoria.bn.br/DocReader/docreader.aspx?bib=720089\&pasta=ano\%20184\&pesq=violao \%20e\%20trompa\&pagfis=701. Acesso em 08/10/2020.

O PAIZ. Noticiario. p. 3, ed. 0012. São Luís, 15 de janeiro de 1878. Disponível em:

http://memoria.bn.br/DocReader/docreader.aspx?bib=704369\&pasta=ano\%20187\&pesq=Domi ngos\%20Thomaz\%20Vellez\%20Perdig\%C3\%A3o\&pagfis=1111. Acesso em 08/10/2020.

PERDIGÃO, Domingos F. M. Publicador Maranhense, P. 4, ed. 3118458. São Luís, 17 de setembro de 1845. Disponível em:

http://memoria.bn.br/DocReader/docreader.aspx?bib=720089\&pasta=ano\%20184\&pesq=violao \%20e\%20trompa\&pagfis $=1218>$. Acesso em 08/10/2020.

PERDIGÃO, Domingos F. M. Publicador Maranhense, p. 4, ed. 497. São Luís, 1o de maio de 1847. Disponível em:

http://memoria.bn.br/DocReader/docreader.aspx?bib=720089\&pasta=ano\%20184\&pesq=violao \%20e\%20trompa\&pagfis=1937. Acesso em 08/10/2020.

PERDIGÃO; VIEIRA. Annuncios. Publicador Maranhense, p. 4, ed. 31. São Luís, 8 de fevereiro de 1874. Disponível em:

http://memoria.bn.br/DocReader/docreader.aspx?bib=720089\&pasta=ano\%20184\&pesq=violao \%20e\%20trompa\&pagfis=22559. Acesso em 08/10/2020.

\section{SOBRE OS AUTORES}

Guilherme Augusto de Ávila é violonista e professor Assistente II no Curso de Música da Universidade Federal do Maranhão -UFMA. Bacharel em Violão pela UFMG (2005); Mestre em Violão pela UFBA (2007), atualmente cursa doutorado em Musicologia Histórica na Universidade Nova de Lisboa - Portugal. Sua tese versa a respeito da proveniência dos documentos musicais do Acervo João Mohana. ORCID: https://orcid.org/0000-0002-3400-9631. Email: guilherme violao@hotmail.com

Daniel Lemos é pianista e professor de música atuante desde 1994. Apresentou-se como solista ou acompanhador em quatorze Estados brasileiros. Teve sua formação com a pianista Maria Luísa Lundberg, os pianistas Miguel Rosselini, Maurício Veloso e Ana Cláudia Assis, com o saxofonista Marco Túlio de Paula Pinto e com o musicólogo João Berchmans de Carvalho Sobrinho. Desde 2009 reside em São Luís, onde é atualmente Professor Adjunto III do Departamento de 
Música da UFMA e Colaborador no Curso de Música Licenciatura EaD da UEMA, possuindo onze livros publicados e dezoito artigos nos principais periódicos brasileiros da área de Música. ORCID: https://orcid.org/0000-0001-7438-3436. E-mail: daniel.lemos@ufma.br

Joaquim Santos é licenciado em Música (UFMA) e especialista em Musicologia Brasileira (UFPI). Desenvolve pesquisa no campo da música maranhense de concerto e da música popular tradicional, com publicaçôes nessa área. É compositor, luthier e professor de violão clássico, harmonia tradicional, funcional e contraponto na Escola de Música do Estado do Maranhão, onde também foi regente de sua Orquestra de Câmara. Integrou a Camerata Carioca atuando ao lado de Radamés Gnattali, participando de gravaçóes com artistas como Nara Leão, Elizete Cardoso, Nana Caymmi, Roberto Menescal e produção artística com Tom Jobim. ORCID: https://orcid.org/0000-0003-3776-1383. E-mail: joaquimsantosneto@hotmail.com 